Portland State University

PDXScholar

\title{
Misconceptions of "Stupendous Antiquities" : Native American Mounds, Euro-Americans, and Racial Ideas
}

Lily Isabelle Hart

Portland State University

Follow this and additional works at: https://pdxscholar.library.pdx.edu/honorstheses

Let us know how access to this document benefits you.

Recommended Citation

Hart, Lily Isabelle, "Misconceptions of "Stupendous Antiquities" : Native American Mounds, EuroAmericans, and Racial Ideas" (2017). University Honors Theses. Paper 484.

https://doi.org/10.15760/honors.488

This Thesis is brought to you for free and open access. It has been accepted for inclusion in University Honors Theses by an authorized administrator of PDXScholar. Please contact us if we can make this document more accessible: pdxscholar@pdx.edu. 


\section{THESIS APPROVAL}

The thesis of Lily Hart for the Bachelor of Arts with Honors in History was presented June 9th, and accepted by the thesis committee and department.

COMMITTEE APPROVALS:

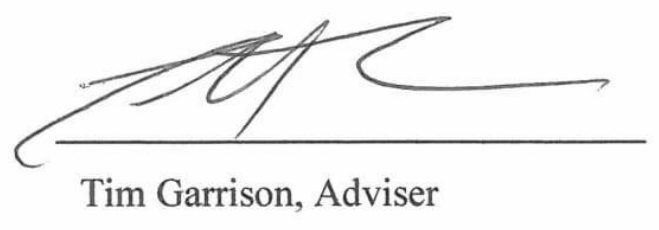

DEPARTMENT APPROVAL:

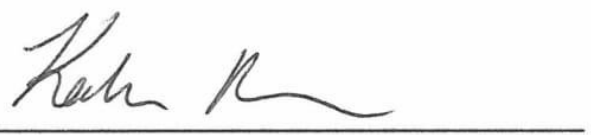

Katrine Barber, Reader

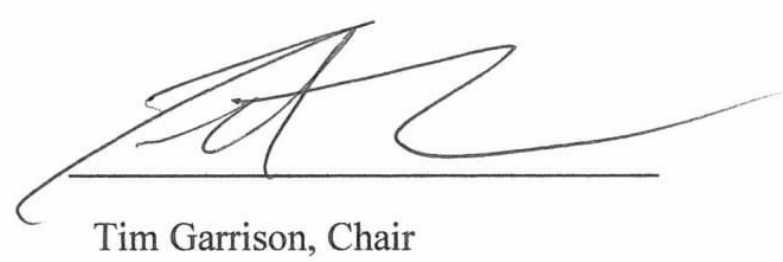

History 


\title{
Misconceptions of "Stupendous Antiquities"
}

Native American Mounds, Euro-Americans, and Racial ideas

By Lily Isabelle Hart

An undergraduate honors thesis submitted in partial fulfillment of the requirements for the degree of

Bachelor of Arts

in

University Honors and

History

\author{
Thesis Advisor \\ Tim Garrison, Department of History \\ Secondary Reader, Katrine Barber
}

Portland State University 


\begin{abstract}
Across North America, remnants exist of the ancient works of Indigenous peoples. Prime examples are the long-abandoned city of Cahokia near present-day St. Louis, Illinois, which was once a bustling city larger than London in 1200 AD. In Cahokia, there are mounds that are as high as one hundred feet and a "Woodhenge" that functions as a calendar. Despite these impressive displays of engineering, urban planning, and understanding of astronomy, Cahokia was not protected as a National Historic Landmark until 1964--this late protection was the case for many of the mounds across America. Many mounds were plowed over and pueblos decayed before this happened. Non-natives attributed these works to other cultures, from Hindus to the Lost Tribes of Israel to the Welsh to aliens. Anglo-Americans of the time were faced with somewhat of a conundrum. They wanted to have antiquities as grand as Rome's, yet they also did not want to admit that these antiquities were built by people that were Indigenous to the Americas. It was rare that a scholar of the time was willing to state that these works were built by the Indigenous inhabitants of North America in the nineteenth century. Oftentimes these theories functioned as a way to dismiss what they called the Indian as savage and incapable of constructing ancient cities; some scholars even put forth that the Indian drove away the people that had constructed the mounds. This thesis puts forth that this way of thinking--the combination of false theories, dismissal of the mounds, and the feeling that the mounds belonged to the white inhabitants of America caused these sites to be neglected. The study of the misconceptions and neglect of the mounds in the nineteenth century demonstrates the attitudes towards race at the time.
\end{abstract}




\section{Acknowledgments}

Thank you for my adviser, Professor Garrison, for helping me form a solid thesis out of what was initially only a vague idea that I wanted to research something on the mounds. He reviewed draft after draft I sent him, even on the weekends which was really appreciated. Thank you to my secondary reader, Professor Barber, for taking the time out of her busy schedule to review this thesis and give thoughtful feedback. And thank you to my family for their support and willingness to read countless drafts, especially to my mother who heard me talking about this thesis the most! 


\section{TABLE OF CONTENTS}

Acknowledgments................................................................ 1

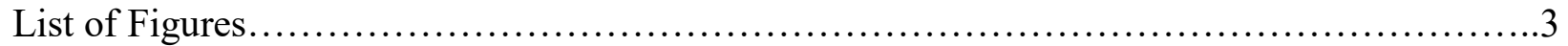

Introduction

"At...the Cahokia Mounds, you touch the pulse of the living planet..."

Misconceptions and Mounds...............................................................

Chapter One

"There are not less than one hundred mounds..."

Cahokia, Chiefdoms and the Mound builders............................................11

Chapter Two

"Those of that people who raised our ancient forests and tumuli."

Euro-American Perceptions of the Mounds...................................................

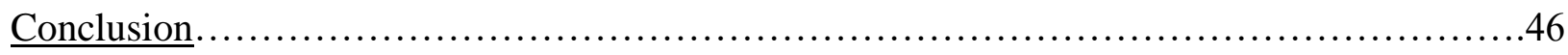

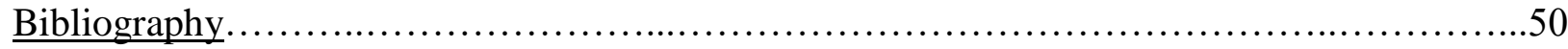




\section{LIST OF FIGURES}

1. Figure 1: Map of Indigenous Mounds in Eastern North America........................................5

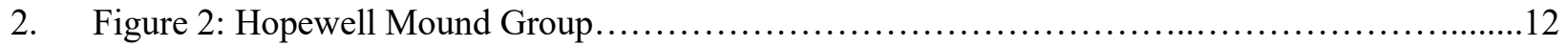

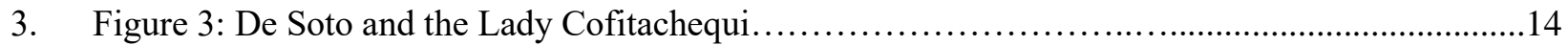

4. Figure 4: An artist's conception of the Emerald Site............................................. 16

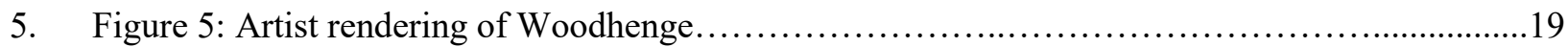

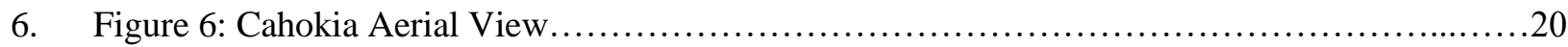

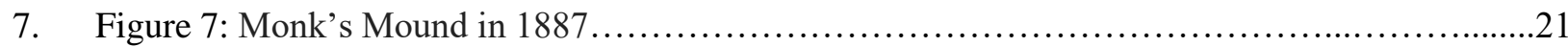

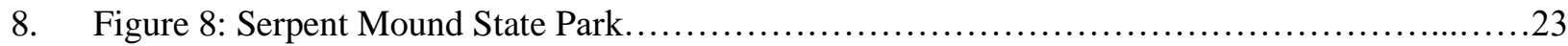

9. Figure 9: Drawing of Alligator Effigy Mound in Licking County Ohio.......................27

10. Figure 10: Depiction of Madoc leaving Wales in 1170 going to America..........................28

11. Figure 11: Drawing of Alligator Effigy Mound in Licking County Ohio.........................32

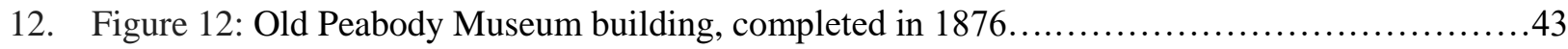




\section{Introduction}

\section{"At...the Cahokia Mounds, you touch the pulse of the living planet..." Misconceptions and Mounds}

Across North America, remnants exist of the ancient works of Indigenous peoples. Prime examples are the long abandoned city of Cahokia near present day St. Louis, Illinois, which was once a bustling city larger than London at the time. At its peak at the turn of the first millennium CE, Cahokia was a heavily populated city, marked by at least one hundred twenty carefully engineered mounds. The city of Cahokia was an impressive feat in urban planning, as it was built to reflect the cardinal directions and celestial alignments. When white settlers or European explorers happened upon these mounds, some, such as James Adair, an eightieth century historian, credited them as built by the lost tribes of Israel. Others, such as Henry Brackenridge, a writer and politician, were appreciative of the mounds as ancient creations, yet frustrated at the lack of notice their discovery was getting. Many Europeans attributed these works to other cultures, from Hindus to the Lost Tribes of Israel to the Mayans. These misconceptions surrounding the mounds can help scholars understand the racial ideas at the time, which were resistant to the truth--that Native Americans had built the prehistoric mounds.

These mounds are important sites to Native Americans. They are sacred sites, tied to spiritual and ancestral history. Kiowa author N. Scott Momaday, wrote that "At Devil's Tower or Canyon de Chelly or the Cahokia Mounds, you touch the pulse of the living planet; you feel its breath upon you. You become one with a spirit that pervades geologic time and space." ${ }^{1}$ These description is apt at describing the significances of the mounds to Native Americans. They are

\footnotetext{
${ }^{1}$ N. Scott Momaday, The Man Made of Words: Essays, Stories, Passages. (Basingstoke, UK: Macmillan, 1998), 114.

${ }^{2}$ Roger G. Kennedy, Hidden cities: the discovery and loss of ancient North American civilization (New
} 
symbols of how long Native Americans have been here--a truth that many white people in the nineteenth century did not want to admit.

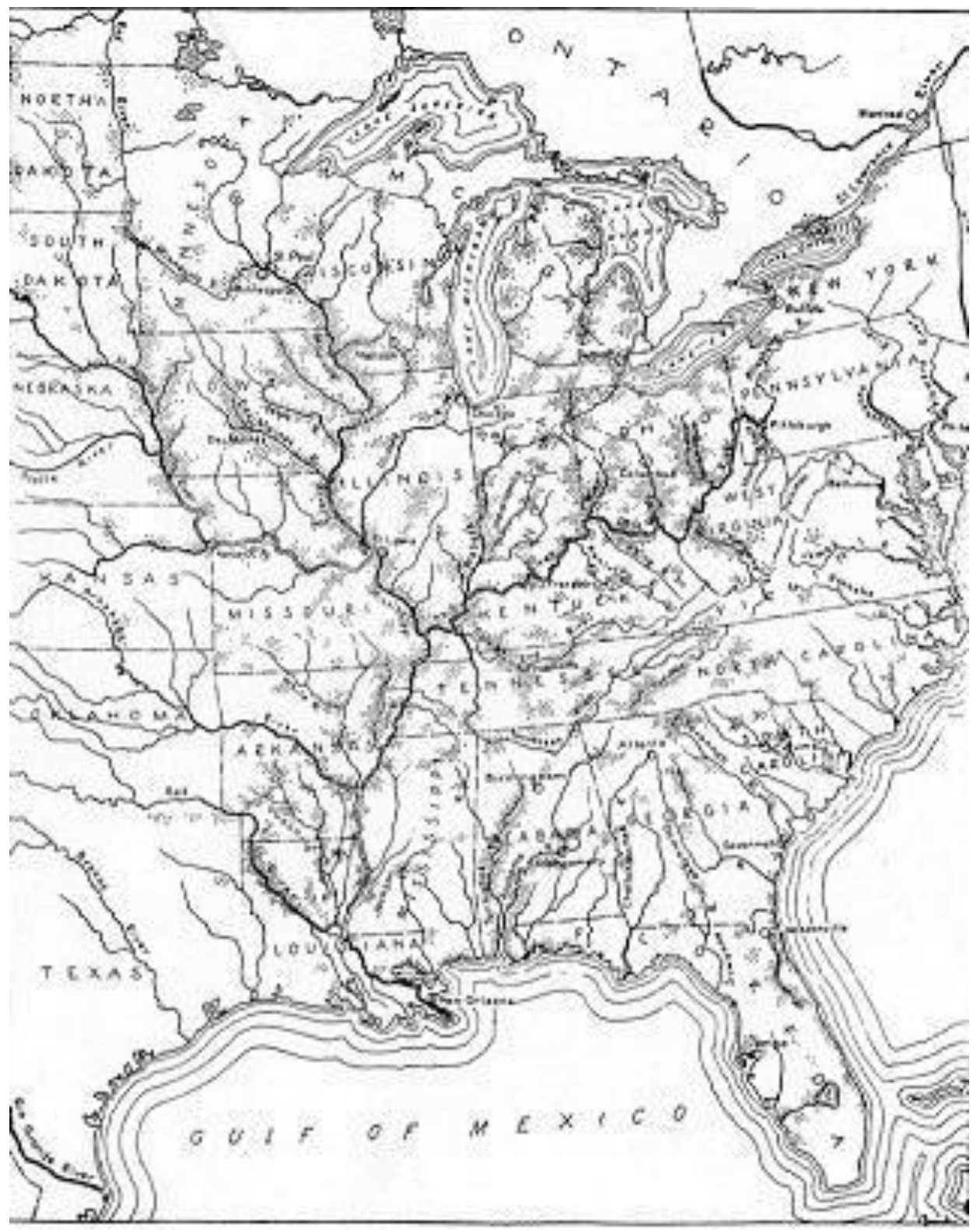

Figure 1: Map of Indigenous Mounds in Eastern North America

It was rare that a scholar of the time was willing to state that these works were built by 
the Indigenous inhabitants of North America in the nineteenth century. Oftentimes these theories functioned as a way to dismiss what they called the "Indian" as savage and incapable of constructing ancient cities; some scholars even put forth that the Indian drove away the people that had constructed the mounds. The result of this way of thinking, of combination of false theories, dismissal of the mounds, and the feeling that the mounds belonged to the European inhabitants of America caused these sites to be neglected.

Anglo-Americans of the time were faced with somewhat of a conundrum. Many wanted to have antiquities as grand as Rome's, yet they also did not want to admit that these antiquities were built by people that were Indigenous to the Americas. Of the numerous studies conducted on the antiquities, only a few attributed them to Indigenous Americans. Scholars such as Edwin Davis or John Clifford wanted antiquates to show that America was just as valid and civilized as Europe - but they did not want these antiquities to be linked to the people whose land they wanted to possess. This resulted in the scholars writing explanations that said the mounds been built by everybody from the Welsh to Israelites to travelers from India.

The intention of these writings is unclear. One would like to believe that these writers genuinely believed in these theories, but the possibility exists that some purposefully put forth these theories in order to steer the conversation away from the Native Americans being the builders. With antiquities being a mark of civilization, acknowledging that they were built by the ancestors of the Indian would have created a complicated contradiction that might have interfered in how people viewed the taking of tribal land.

This thesis is a study of how the viewpoints of non-native settlers and explorers shaped the future of the antiquities of North America. North America is a site of impressive feats of architecture and urbanization, yet they have not been tended to with the care that other world 
heritage sites have been. The mixture of the confusion of early writers and the effects of colonization has contributed to this.

Urbanization took a toll on the mounds and is still a threat in recent years. By 1948, the mounds in North America had been reduced by ninety percent. ${ }^{2}$ As urban development increased, farmers grew crops on ancient mounds, golf courses were put up among the mounds, and the building of roads also threatened them.

Circleville, Ohio, is a good example of the damage urbanization caused. The town was founded in 1810, named after the circular mounds that were in the area. Around 1830, residents grew tired of the town's shape and wanted something more normal. James S. Buckingham, an author and journalist from England, wrote an observation of Circleville that stated "So little veneration...have the American for ancient remains...that Circleville is soon likely to lose all traces of its original peculiarities." ${ }^{3}$ He was right. Circleville went through an urban renewal to square the town, losing its circular layout and mounds in the process. It started around 1838, two years before Buckingham traveled through and witnessed how the town looked in an in-between state, where there were still remnants of antiquities while the town was giving away to modern urbanization. The urban renewal came as a result of the Circleville Squaring Company which did as the name suggested: square the town. Other ancient mound squares, such as the ones in Newark and Marietta, were destroyed; Marietta to leveling and Newark to a railroad.

Serpent Mound, one of the most striking effigy mounds, nearly suffered a similar fate. There were attempts to build on it and level it, but Frederic Putnam—a director of the Peabody Museum--saved it. ${ }^{4}$

\footnotetext{
${ }^{2}$ Roger G. Kennedy, Hidden cities: the discovery and loss of ancient North American civilization (New York: Free Press, 1994), 239

${ }^{3}$ Ibid, 24.

${ }^{4}$ Kennedy, 241.
} 
The neglect of these sites and the decay that occurred has garnered more study in the last few decades. Roger G. Kennedy, a historian, director of the Smithsonian Institution's National Museum of American History, and a head of the National Park Service, offered a theory for why Americans ignored Cahokia and its achievements. In Hidden Cities: The Discovery and Loss of Ancient North American Civilization, he wrote that the American notion of Manifest Destiny pushed the awareness of these ancient cities out of the public eye. Americans who thought it was acceptable to plow the mounds and turn them into farmland believed it was their destiny to be on that land. ${ }^{5}$ For Americans to admit that ancient, advanced civilizations had existed long before white settlement would require them to admit that their ancestors might have been responsible for destroying and dispossessing the descendants of these cities. In acknowledging these cities, they would have also admitted that American civilization existed long before 1492. To pinpoint exactly why attitudes about Cahokia changed is difficult. It could be due to the loss of faith in Manifest Destiny by the American people, the emergence of professional archaeology and anthropology, or simply the emergence of a larger public that was becoming more and more curious about the unusual creations they passed by every day.

Native perspective is often missing from the study of the mounds; a gap that Barbara Mann began to fill in her book Native Americans, Archaeologists, and the Mounds. Mann is a professor at the University of Toledo and is of Seneca tribal descent. Her book is a thorough and often sarcastic study of the treatment of the mounds and misinformation that existed about them. It is a detailed scholarly work and one that includes the Native perspective and attitude with pride. She writes that "I will ride that undead horse of Native discourse, being direct and

\footnotetext{
${ }^{5}$ Roger G. Kennedy, Hidden cities: the discovery and loss of ancient North American civilization (New York: Free Press, 1994),
} 
unapologetic in my use of bold language and oral tradition." ${ }^{6}$ Mann's work covers archaeologist's perspective of the mounds dating back to the eighteenth century, the neglect of native perspectives and oral histories to determine the mound's history, and the raiding of burial mounds and the influence of NAGPRA to protect the remains.

The perceptions of Native Americans by whites is traced in The White Man's Indian by Robert Berkhofer, from the "savage" perception to the new age obsession with native culture. Berkhofer was a professor at many universities, including Santa Cruz. In his book he separates image, idea, and stereotype. He wrote that the "image is the more literal, even pictorial representation...stereotype designates any image today we no longer find accurate....to me idea is a conceptual category." Berkhofer pointed out that it was whites who created the idea of what an "Indian" was. Native Americans were made out of numerous cultures, civilizations, and tribes, yet in many people's minds, even today, they exist as one entity. Berkhofer discussed the various ideas relating to the origins of Indigenous people and the racial ideas tied to those.

Berkhofer wrote that in his work he uses Native American when referring to the actual Native people and Indian when referring to the image white people had of native people. I will be adopting a similar tactic—generally I will use Indigenous, to emphasize the indigenous nature of these mounds, but when referring to the white perceptions I will use Indian or "modern Indian." This is also to avoid confusion, since some primary documents use "aboriginal" or "indigenous" when referring to the mound builders, although who they are referring to is a mystically vanished white race.

\footnotetext{
${ }^{6}$ Barbara Mann. Native Americans: Archaeologist, and the Mounds. American Indian Studies. v. 14. (Bern, Switzerland: Peter Lang Incorporated, 2003) 4.

${ }^{7}$ Robert F Berkhofer, The white man's Indian: images of the American Indian, from Columbus to the present, Ann Arbor, MI: The University of Michigan, 1979, Xvii B
} 
The confusion and contradictory theories about the mounds cancelled each other out an, despite some passionate interest, most of the mounds were neglected. Through my exploration of the history of the perceptions of the mounds and the neglect of them, I discovered that the treatment and ideas surrounding the mounds are a glimpse into the views in the nineteenth century towards Indigenous people. Some of the theories seem ridiculous now, such as one that a Welsh prince built the mound, but they shine light onto the struggle over the New World and racial ideas at the time. 


\section{Chapter 1}

\section{"No less than one hundred mound..." \\ Cahokia, Chiefdoms and Mound builders}

In order to properly understand the various interpretations of the mounds, it is helpful to have a clear idea of what Cahokia, chiefdoms, and the mounds looked like and how they functioned.

Mound Building culture stretched across North America and over several centuries. Mound building culture is mainly found in what are divided into three different cultures. Adena $500 \mathrm{BC}$ to $100 \mathrm{BC}$ to Hopewell, $100 \mathrm{BC}$ to $800 \mathrm{AD}$, and Mississippian, after $800 \mathrm{AD}$. These are not ways of categorizing tribes, but based on evidence of a similar way of life in a certain stretch of time.

The Adena culture was marked by the strong development of agriculture and villages. Mounds such as Gravesville Mound in West Virginia, which is 292 feet high, making it the largest conical mound in North America, and the complex of twenty-two conical mounds known as the Wolf Plains in Ohio, are attributed to the Adena. ${ }^{8}$

The Hopewell period was marked by an increase in agriculture and a strong trading network. The Hopewell culture included inter-village exchange, and residents acquiring and exchanging raw materials, such as mica, pipestone, and meteorite iron. There was a presence of crescent shaped artifacts found in Hopewellian culture, which is significant when it comes to the alignment discovery. As the Hopewell societies built mound complexes and villages, the culture also gave rise to the beginning of chiefdoms. As societies became more intricate and structured, leaders emerged. ${ }^{9}$

\footnotetext{
8 Albert C. Spaulding, "The Origin of the Adena Culture of the Ohio Valley." Southwestern Journal of Anthropology 8, no. 3 (1952): 260-68. http://www.jstor.org/stable/362865

${ }^{9}$ Patricia Kay Galloway, Choctaw Genesis, 1500-1700. (Lincoln, NE: University of Nebraska Press, 1998), 37.
} 


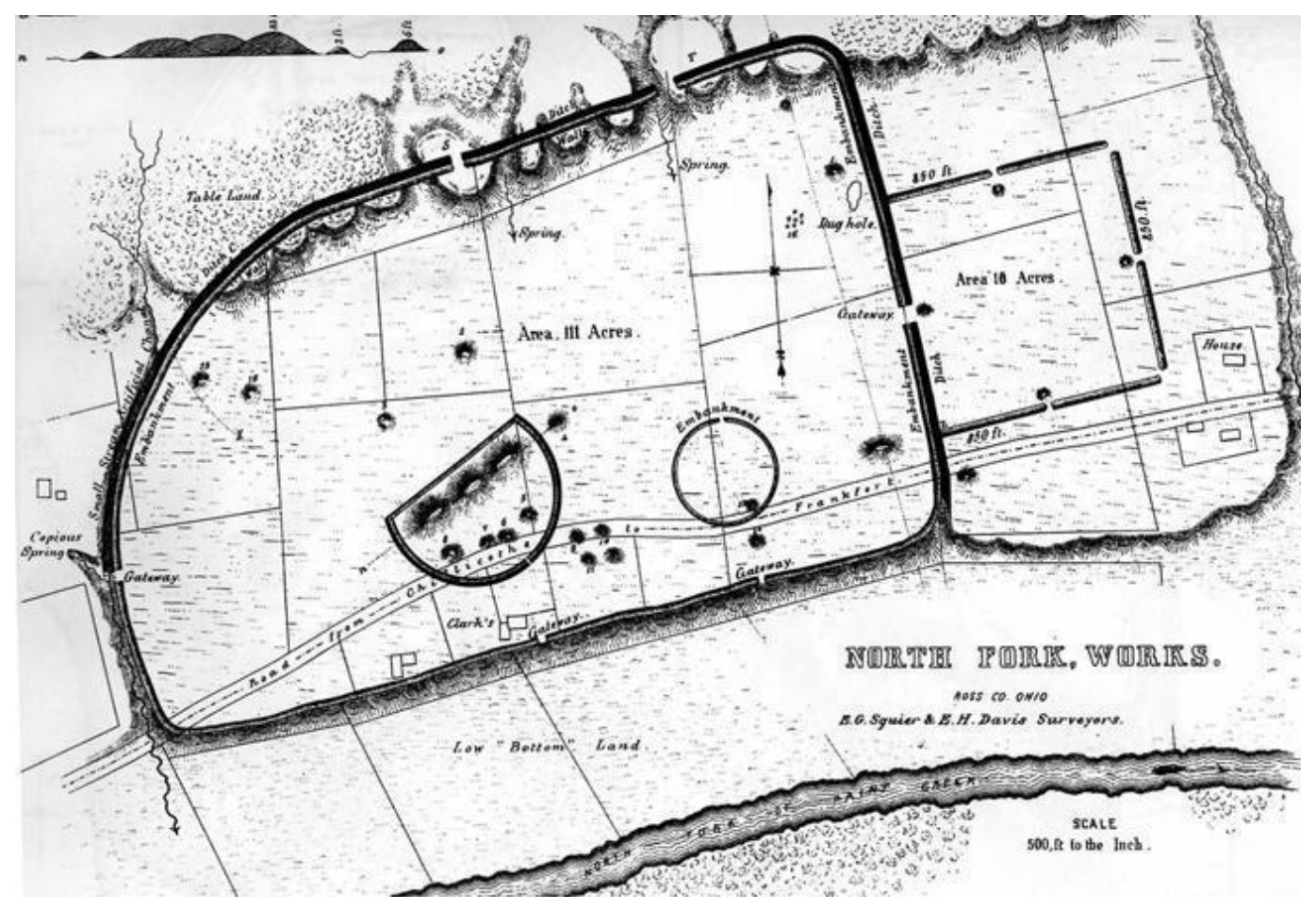

Figure 2: Hopewell Mound Group,

Squier and Davis 1848, National Park Service. ${ }^{10}$

The Mississippian culture marked by chiefdoms and sun worship. A chiefdom leader

often lived on a platform mound, which he or she ruled from. Chiefdom societies were intact as late as the 1700s. The Spanish encountered chiefdoms in the sixteenth and seventeenth centuries and in the Grand Village of the Natchez chiefdom, in Mississippi, there were three platform mounds that were in use as late as the early eighteenth century. ${ }^{11}$

Charles Hudson explained chiefdoms as being a status in between tribes and the more rigid state structure of the Inca or Maya. States were held together organically, with rulers in the cities and the lower class in towns. The structures of tribes were held together more "mechanically" by associated groups. ${ }^{12}$ In chiefdoms, it was something in between. The Southeastern people had a hierarchy, that ranked citizens from highest to lowest, often based on

\footnotetext{
10 Squier and Davis, https://www.nps.gov/hocu/learn/historyculture/hopewell-mound-group.htm

11 James F. Barnett, Mississippi's American Indians. (Jackson, MS: University Press of Mississippi, 2012$) 43$.

$12{ }^{12}$ Charles Hudson, The Southeastern Indians. (Knoxville, TN: Tennessee University Press, 1976), 202.
} 
age and background, such as leadership, warrior status, and accomplishments in religious and medical fields. ${ }^{13}$ Rather than commanding, chiefs were leaders. The leaders often inspired great loyalty in their followers. When Hernando De Soto tried to invade the chiefdom of Cofitachequi, he tortured a number of residents to death to obtain information on where the paramount chief was, information none of them would reveal. ${ }^{14}$

Hernando De Soto was a Spanish conquistador who traveled from Florida to the Mississippi in 1539. At the time of his travel, there were still people living among mounds that were built throughout the Americas, although Cahokia had long been abandoned. The Spanish were mostly concerned with finding gold and conquering the Indigenous tribes in the process, so while the journals of the expedition lend interesting descriptions to modern scholars, they did not care much for the remarkable culture they were experiencing and often tried to capture leaders.

Some of the sites they visited was the aforementioned Cofitachequi, which had eight mounds and is most likely where the present day Mulberry site is located in South Carolina. Cofitachequi's main town was located near Augusta, Georgia and the Savannah River. The expedition was surprised to find that the leader was a woman. She was referred to the Lady of Cofitachequi and given no name. She apparently greeted them warmly, and mentioned that the food was scarce because there had been plague that had affected their crops and killed off some of her citizens. Near the main village lay Talamico, which was the religious center for Cofitachequi. The main temple was on top of a high mound and the mound itself was 100 feet long, 40 feet wide, -and the town itself had five hundred houses. The temple was elaborate, with numerous statues inside. ${ }^{15}$

\footnotetext{
${ }^{13}$ Charles Hudson, The Southeastern Indians. (Knoxville, TN: Tennessee University Press, 1976), 202-203.

${ }^{14}$ Charles Hudson, The Southeastern Indians. (Knoxville, TN: Tennessee University Press, 1976), 204.

${ }^{15}$ Charles Hudson, The Southeastern Indians, 109-111.
} 


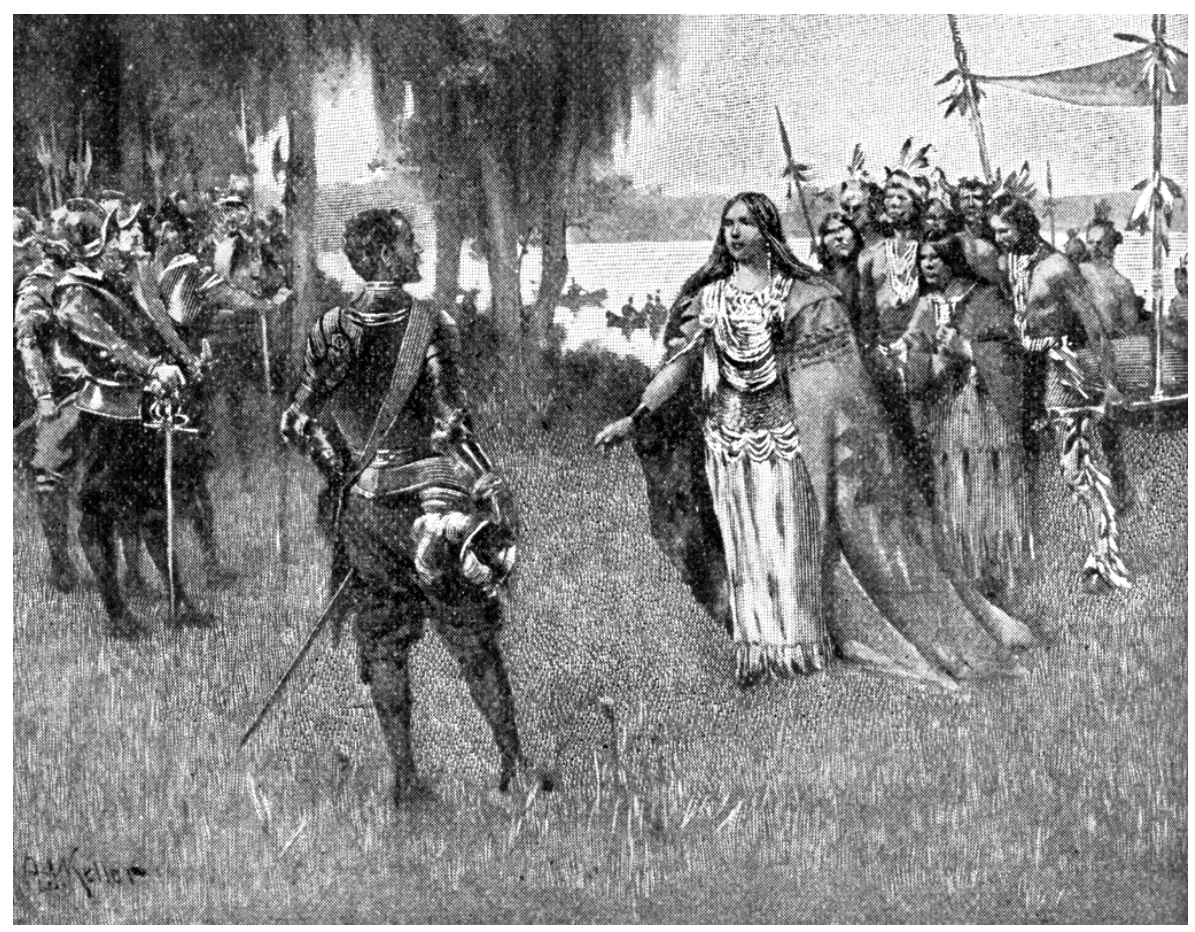

Figure 3: De Soto and the Lady Cofitachequi ${ }^{\mathbf{1 6}}$ Caroline Mays Brevard, A History of Florida

Despite the warm welcome by the Lady of Cofitachequi, De Soto's expedition responded by capturing her and raiding the main temple for the pearls in contained. According to the expedition's diarist, the Lady ended up escaping with a slave owned by De Soto.

De Soto also encountered chiefdoms in Alabama. The leader they encountered was Chief Tuskaloosa who would later face them in a Trojan horse style battle, which became known as the Battle of Maliba. However, before the battle occurred, the Spanish visited Tuskaloosa at the plaza of his court. There they took him hostage, and he in turn likely took two of their men hostage, who he told them they would find in the village of Maliba. At Maliba he told them to leave in peace, and when they would not, his warriors attacked. Gonzalo Fernández de Oviedo wrote an account of the expedition, where he related what Rodrigo Ranjel, the diarist, wrote following the first encounter.

\footnotetext{
${ }^{16}$ Caroline Mays Brevard, A History of Florida (New York: American Book Company, 1904) 32.
} 
Governor entered the village of Tascaluqa [sic Tuskaloosa], which is called Athahachi, a recent village. And the chief was on a kind of balcony on a mound at one side of the square, his head covered by a kind of coif like the almaizal... the Governor entered the plaza and alighted from his horse and went up to him, he did not rise, but remained passive in perfect composure and as if he had been a king. ${ }^{17}$

Tuskaloosa was indeed the king or an equivalent of one. Despite this fact, the Spanish would take him captive, which prompted him to stage the Battle of Maliba--which he lost. It is unclear how many mounds there were in Tuskaloosa's chiefdom but if there was one "mound at one side of the square" then there was likely to be more. In fact, the description of the plaza harkens back to Cahokia and the great plaza they had leveled. It would be unsurprising if the mounds in Tuskaloosa's city dated back to the age of the Cahokia ones. Unlike Cahokia, it was still inhabited in the sixteenth century.

The chiefdom of the Natchez lasted in the lower Mississippi valley, until the 1730s. Natchez was chiefdom along the lower Mississippi valley. Their system had one of the most powerful chiefs, which they called the Great Sun. The Sun lineage was interpreted by the French as the noble class. The Sun people could not marry other Suns and the offspring of Sun women became Suns, but not the offsprings of Sun men. ${ }^{18}$ The system of governing and class was intricate and tied closely with the sun.

17 1.3 Gonzalo Fernández de Oviedo y Valdés, The General and Natural History of the Indies in Colonial North America and the Atlantic World: A History in Documents by Brett Rushforth and Paul Mapp (Abingdon: UK, Routledge, 2016)

${ }^{18}$ Charles Hudson, The Southeastern Indians, 207. 


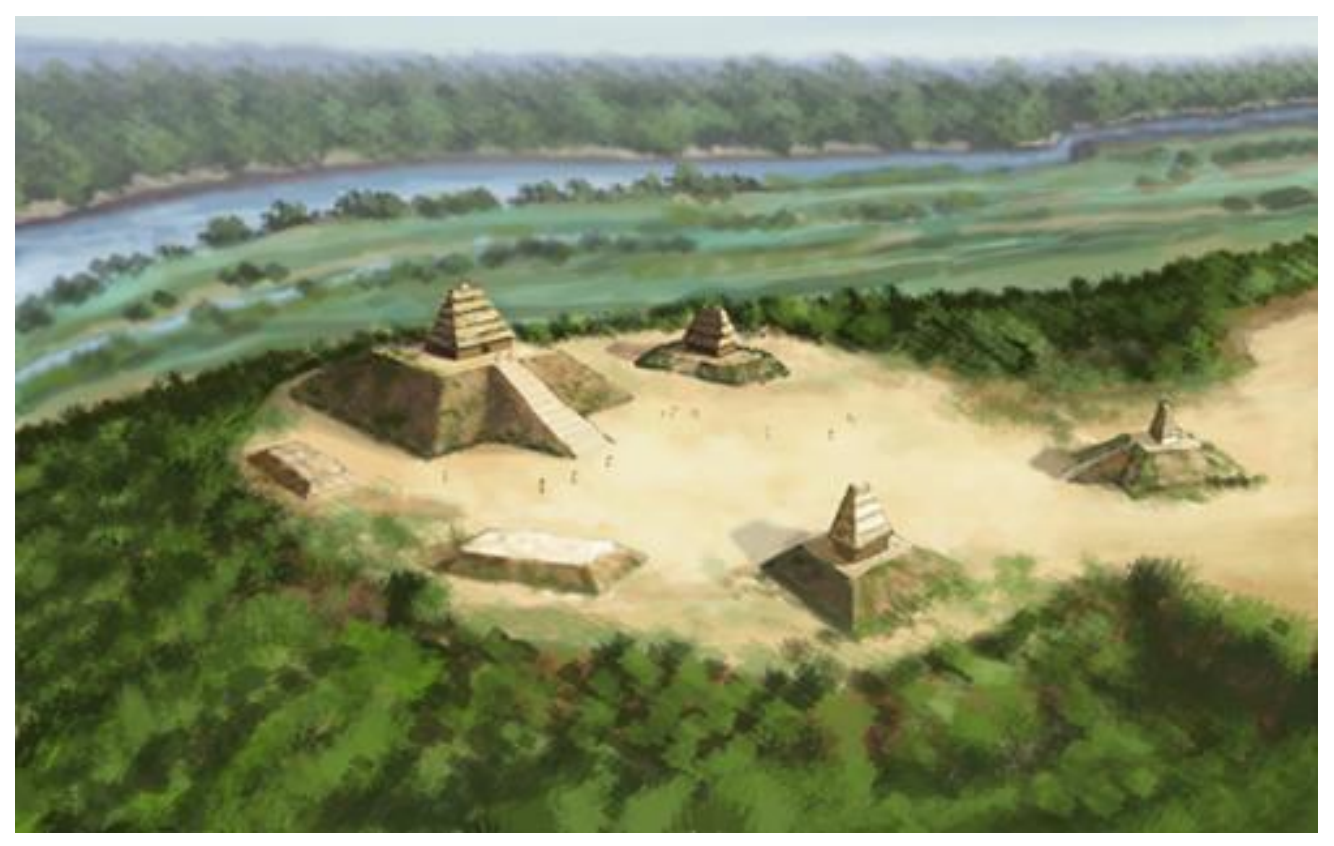

Figure 4: An artist's conception of the Emerald Site, (22 AD 504) Herb Roe, Wikipedia Commons

Like most chiefdoms, Natchez was a mound site. The largest mound was the Emerald Mound, which was 35 feet high and covered a total of eight acres. On top of the primary mound sat two additional mounds, and researchers believe that there used to be six small mounds on top of the primary mound at one time. De Soto expedition also recorded riding their horses up to the flat tops of the temple mounds. ${ }^{19}$ The Natchez society ended around 1730, when the Natchez and French engaged in conflict. Many of the Natchez ended up joining the Chickasaws, as well as the Cherokees, Catawbas, and Creeks. The Adena, Hopewell, and Mississippian cultures show the increasing development of urban planning and the growth of societal structure.

A major site was Cahokia. Cahokia was a city that in its peak around $1000 \mathrm{BC}$ had more than a hundred mounds, with a central plaza, a thriving agriculture and smaller houses for

\footnotetext{
19 “Emerald Mound," Natchez Trace Parkway. National Park Service US Department of the Interior. https://www.nps.gov/natr/planyourvisit/upload/Emerald-Mound-2013-for-web.pdf
} 
residents to live in. Cahokia was situated near present day Collinsville, Illinois. Today, as a state historic site, it is managed by the Ohio Preservation Society. Visitors can come to the remains of Cahokia, located near present day St. Louis and view the eighty mounds that are left, as well as the re-creation of Woodhenge. It offers an interpretive center and events such as the Fall Equinox Observation, ceremonies, American Indian Markets, and Kid's Days.

A key researcher of the Cahokia site is William Iseminger. He is the assistant site manager at Cahokia mounds. He has worked there for more than forty years and has extensive knowledge of Cahokia. His book, Cahokia Mounds: America's First City, is a detailed study of Cahokia as a metropolis and how it was planned. He presents the thesis that Cahokia is America's first city and the "largest prehistoric settlement in North America."20

Despite the fact Cahokia was an impressive example of urbanization, the once great city was used by Trappist Monks as a garden, plowed over by farmers, raided by John Smith’s expedition for artifacts - including human remains--and dismissed by many scholars of the nineteenth century.

The long delay in preserving Cahokia was tragic, for the Mississippian civilization played a significant role in the history of indigenous North Americans. The mounds were built entirely by hand, with no support from wheels or wagons. Building mounds of those heights, some as tall as one hundred feet high, would have taken years. ${ }^{21}$ The exact purpose of each mound is unclear. Some functioned as burial mounds and others were perhaps used for ceremonial purposes or as defenses. It is clear, however, that Cahokia was laid out in accordance with the cosmos, with special attention to the sun and solstice. The mounds at Cahokia were placed in accordance with the four cardinal directions, with the equinox sunset and sunrise as foci. The summer and winter

\footnotetext{
20 William Iseminger, Cahokia Mounds: America's First City. Mount Pleasant SC: Acardia Publishing, 2010.31.

${ }^{21}$ Cahokia Mounds: Ancient Metropolis, Ancient America. VHS.
} 
solstice were also significant markers in Cahokia architecture. Pottery Mound, for instance, is oriented to the winter solstice. If one were to look at the city from the sky, it would appear to have been laid out in the form of a cross. ${ }^{22}$

The Cahokians planned the mounds with purpose. They built three different types: platform, ridge top, and conical. ${ }^{23}$ They used the ridge top and conical mounds to bury important people and to mark specific locations. The platform mounds functioned as temples of religion or government. ${ }^{24}$ The relationship between mounds is important. Some were plotted so that their relationships to each other reflected celestial alignments. For example, there is a meridian linehalf of an imaginary circle on the surface of the Earth — that falls between Monks Mound, Mound 66, and Mound 72. ${ }^{25}$ The fact that these mounds were connected via an astronomical alignment shows how purposeful the Cahokians were in their planning. They were not randomly built, but planned to function together to reflect the cosmos and sky. Clearly, the Cahokians were astute at urban planning and engineering.

The solstice was a key aspect of Cahokia's planning. Archaeologists have identified five great circles in Cahokia, varying in size, which they call Woodhenge. Wooden poles were aligned into the circles, and if one stood in the middle of a circle at the right time, you could tell the seasons by the sun hitting the markers for the solstices and the equinoxes. If one looked at the sunrise post in the main circle of Woodhenge, the sun would look as though it were rising out of Monks Mound, which was likely the home of the Cahokian paramount chief. ${ }^{26}$ Today, one can find a reconstruction of the third circle at the site. Woodhenge played an instrumental role in the

\footnotetext{
22 "Cahokia Layout," Illinois State Museum. museum.state.il.us

${ }^{23}$ Iseminger, Cahokia Mounds, 121-135.

${ }^{24}$ Ibid, 34.

${ }^{25}$ Giulio Magli, Mysteries and Discoveries of Archaeoastronomy: From Giza to Easter Island (Springer Science \& Business Media, 2009), 129

${ }^{26}$ Iseminger, Cahokia Mounds, 83.
} 
lives of the residents of Cahokia by telling them the time of day, the season, and the dating of festivals and religious days.

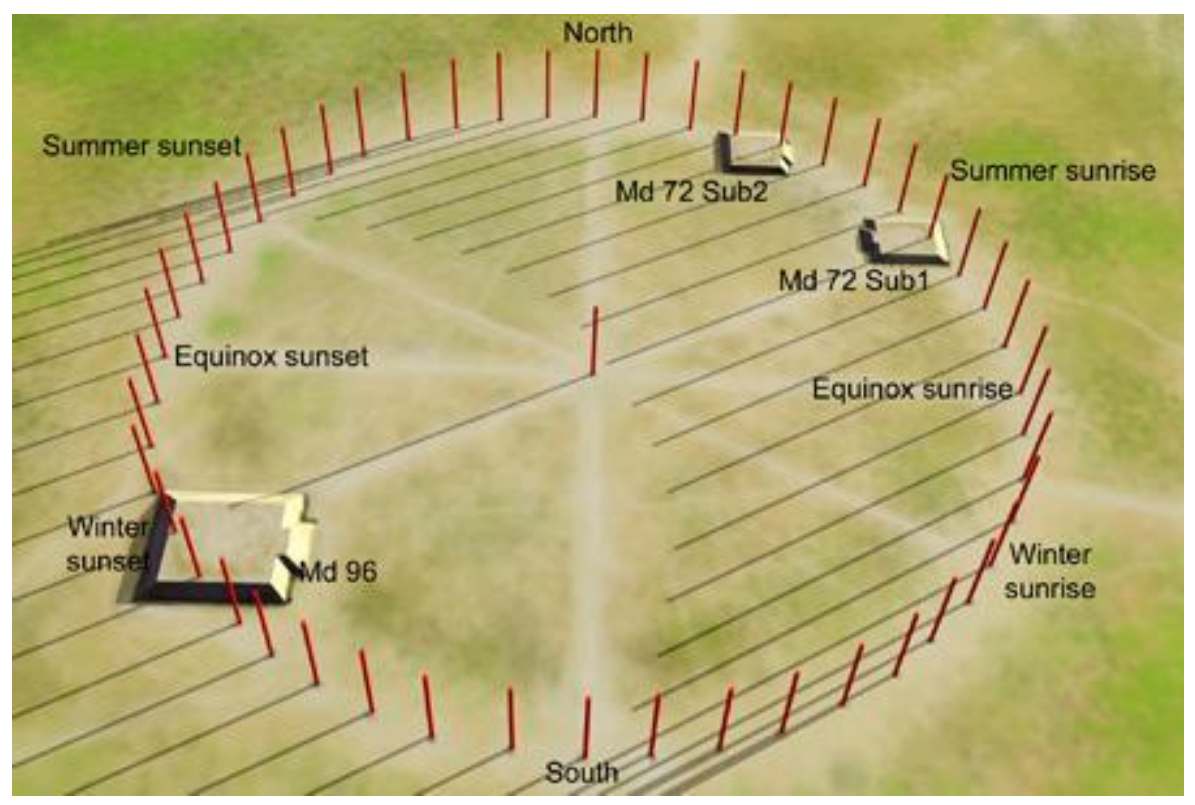

Figure 5: Artist rendering of Woodhenge Herb Roe, Wikipedia Commons

Mound 72 was a surprising discovery for researchers. The mound functioned as a burial mound for more than 250 bodies, with the burial pits and corpses aligned to sunrises, sunsets, and directional markers. ${ }^{27}$ It is uniquely oriented on a northwest to southeast axis rather than a north to south axis like the other mounds. Ancient Cahokians built Mound 72 on top of a site of a former Woodhenge, which makes it even more interesting. ${ }^{28}$ Because of this, many anthropologists surmise that the elite of the community were buried there, with their bodies oriented towards the sunrise solstice post. The Beaded Burial is the best example of an astronomical alignment burial. Because his corpse was surrounded by 20,000 beads formed from marine shells, scholars believe that the man was a chief, buried in grandeur like the leaders of

\footnotetext{
${ }^{27}$ Iseminger, Cahokia Mounds, 83.

${ }^{28}$ Timothy R. Pauketat, Ancient Cahokia and the Mississippians (Cambridge: Cambridge University Press, 2004), 88-93.
} 
ancient Egypt. Mound 72 also held individuals who appeared to have died in violent ways, either by sacrifice or as punishment. ${ }^{29}$ While there are many mysteries left when it comes to Mound 72 and who was buried there, it is clear that the celestial alignments within it were important.

Monks Mound is perhaps the most impressive mound at Cahokia. It is a massive platform mound, one hundred feet high, with four terraces. At the top of the mound was a building that was likely around fifty feet tall. ${ }^{30}$ It was there that the leader of Cahokia lived and governed. As far as we know, Monks Mound was the largest prehistoric structure in the Western Hemisphere. Below Monks Mound was a central plaza, which the people had intentionally leveled. People probably held markets there, socialized, and played games such as chunkey. Chunkey was a game in which the participants threw spears at a rolling stone disk, with the winner landing a spear nearest to the chunkey stone. Thousands of chunkey stones have been discovered at Cahokia and other Mississippian sites.

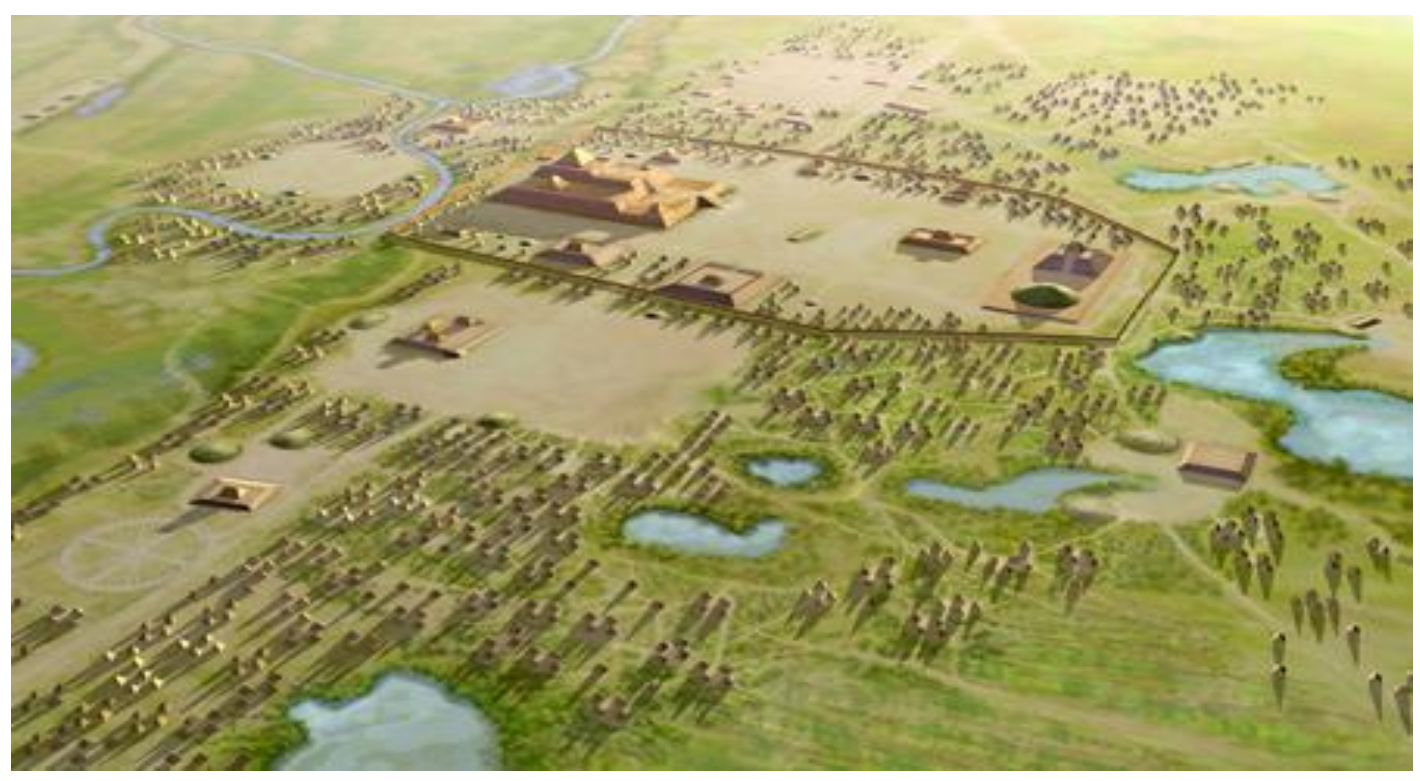

Figure 6: Cahokia Aerial View Herb Roe, Wikipedia Commons

\footnotetext{
29 "Mound 72," University of Wisconsin Milwaukee. http://www4.uwm.edu/archlab/cahokia/mound72.cfm

${ }^{30}$ Cahokia Mounds: Ancient Metropolis, Ancient America. VHS.
} 


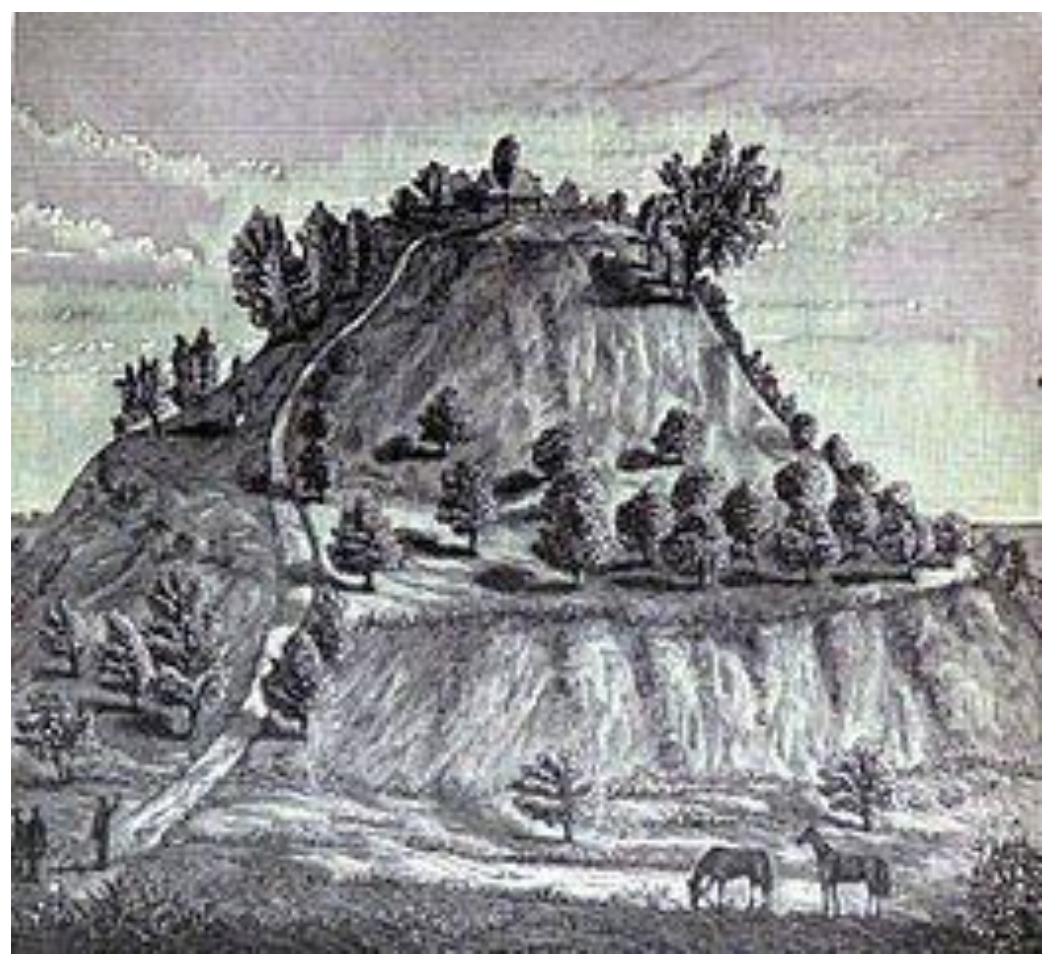

Figure 7: Monk's Mound in 1887

Records of Ancient Races in the Mississippi Valley by William McAdams (1887)

As more and more non-natives flocked into America, the mounds became used as living spaces. Monks Mound got its name because a group of Trappist monks settled there in 1809. A man named Nicholas Jarrot, who had claimed ownership of the area, gave the land to the monks. The monks actually lived on the smaller mounds nearby, building around eighteen log cabins on them, and used Monk's Mound as a surface for growing wheat and vegetables. They left in 1813 after they suffered from a typhoid fever epidemic and their gardens failed. They left the Cahokia area a little worn for the wear, having used the mounds for both living and gardening. ${ }^{31}$

John Kelly and James Brown put forth the case that Cahokia was a powerful example of urbanism and that it proved that urbanism and urban planning existed in North America. Brown , a professor of anthropology at Northwestern University, and Kelly ,a professor at Washington

\footnotetext{
${ }^{31}$ G.J. Garraghan, “The Trappist of Monks Mound,” Illinois Catholic Historical Review 8, no. 2 (Oct. 1925), 106-136.
} 
University in St. Louis, proposed that the planning of Cahokia is based on cosmology, which would include astronomy, the earth, people, and opposites. The focus was on the balance in the cosmos, such as night and day, large mounds and small mounds, and the representation of male and female. Kelly and Brown also argue that the event of either the Supernova of 1054 or Haley's Comet around 1066 influenced the abrupt arrival of people coming to live in Cahokia and its general area.

Another example of mounds is the Newark Earthworks in Ohio. In 1982, Ray Hively and Robert Horn wrote a paper studying the astronomical alignments within Newark Earthworks and found a strong moon alignment. ${ }^{32}$ The Newark Earthworks are geometric mounds that are 3,000 acres in extent, making it the largest earthen enclosure in the world. They were built during the Hopewell period, around $500 \mathrm{BC}-500 \mathrm{AD}$. The astronomical aspect of the paper centered on the alignments of the sun, moon, and planets to the earthworks.

The Newark structures can be used to do a fairly accurate monitoring of the 18.6-year lunar cycle, as well as the monthly one. In the Octagon circle, the axis points towards the maximum northern rising point of the Moon, with little inaccuracy. The midline area of the Octagon walls aligns with extreme rising and setting points of the Moon. There are similar lunar alignments in other Newark Earthworks--not just in the Octagon--and even similar alignments at other Hopewellian sites. From the Octagon to the Observatory Circle, there is an avenue that can be used for monitoring the cycle.

On the avenue connecting the Octagon to the Observatory Circle, Hively and Horn say that:

An observer sighting along the southern parallel of the avenue would be looking at the maximum northern extreme lunar rise point with 0.1 ; an observer sighting along the northern parallel would be looking at the same lunar even within 0.3. An observer sighting diagonally across the avenue would be looking at the minimum northern

\footnotetext{
${ }^{32}$ Both are professors and scholars, with Hively teaching at Earlham College and Horn at Harvard and Columbia.
} 
extreme rise point within about $0.2 .^{33}$

In short, this means that an observer that is standing in the entrance of the avenue could only see the Moon rise when the Moon was between the both maximum and minimum extreme northern points, which leads the observer to be able to monitor the 18.6 lunar cycle.

This evidence further backs up the theory that the lunar alignments were intentional For what reason is unknown, though due to the fact there were at least five crescent-shaped mounds at the Earthwork site, as well as crescent artifacts among Hopewellian culture, one could guess that the society in that area placed great importance on the moon.

The effigy mounds were another popular design for the mound builders. Unlike Cahokia and the Octagon mounds, an effigy mound was built in the shape of animal, usually one of religious importance. The Serpent Mound is one example-- it is located in Adams County, Ohio and was added to the National Register of Historic Places in 1966. The mound is literally in the shape of a 1,348 long serpent. ${ }^{34}$ Considering the length, it can only be seen in full from the sky, which made the construction of it intriguing.

\footnotetext{
${ }^{33}$ Ray Hively and Robert Horn, "Geometry and astronomy in prehistoric Ohio," Journal for the History of Astronomy 13, no. 4 (1982): S1-S20.

${ }^{34}$ Glotzhober and Lepper, Serpent Mound: Ohio's Enigmatic Effigy Mound, Ohio Historical Society, Columbus, Ohio, 1994, p. 3
} 


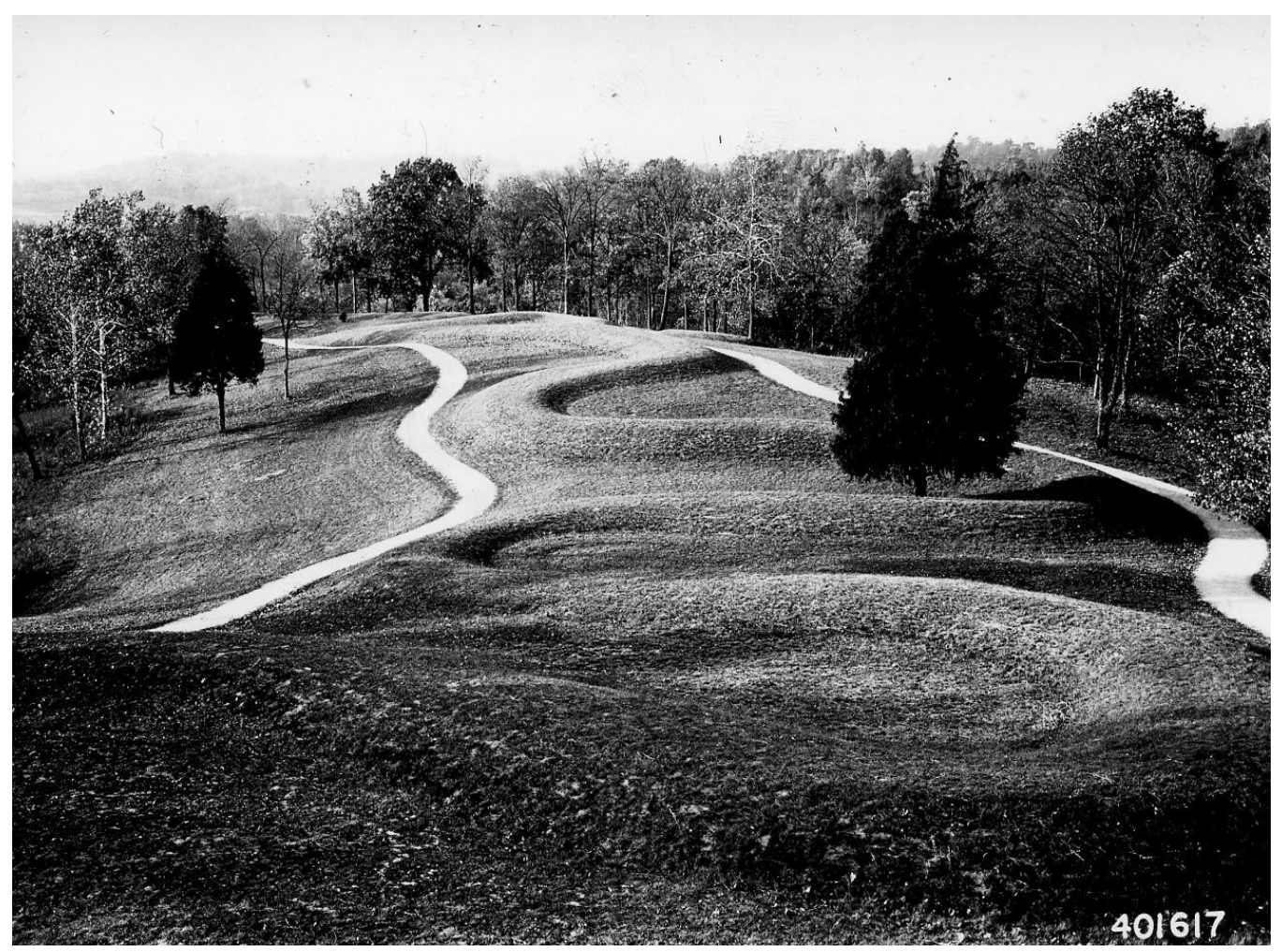

Figure 8: Serpent Mound State Park

U.S. National Archives and Records Administration

The design for effigy mounds range widely, from the serpent to alligators. The subject of their design is sometimes debated to this day. The Alligator mound is regarded widely to be in the shape of an alligator, though some, such as archeologist Brad Lepper, suggest it was supposed to be an underwater panther, a figure important in traditional stories. ${ }^{35}$

\footnotetext{
${ }^{35}$ Brad Lepper and Tod A. Frolking, "Alligator Mound: Geoarchaeological and Iconographical Interpretations of a Late Prehistoric Effigy Mound in Central Ohio, USA," Cambridge Archaeological Journal, 2003. 13 (2): 147-167
} 


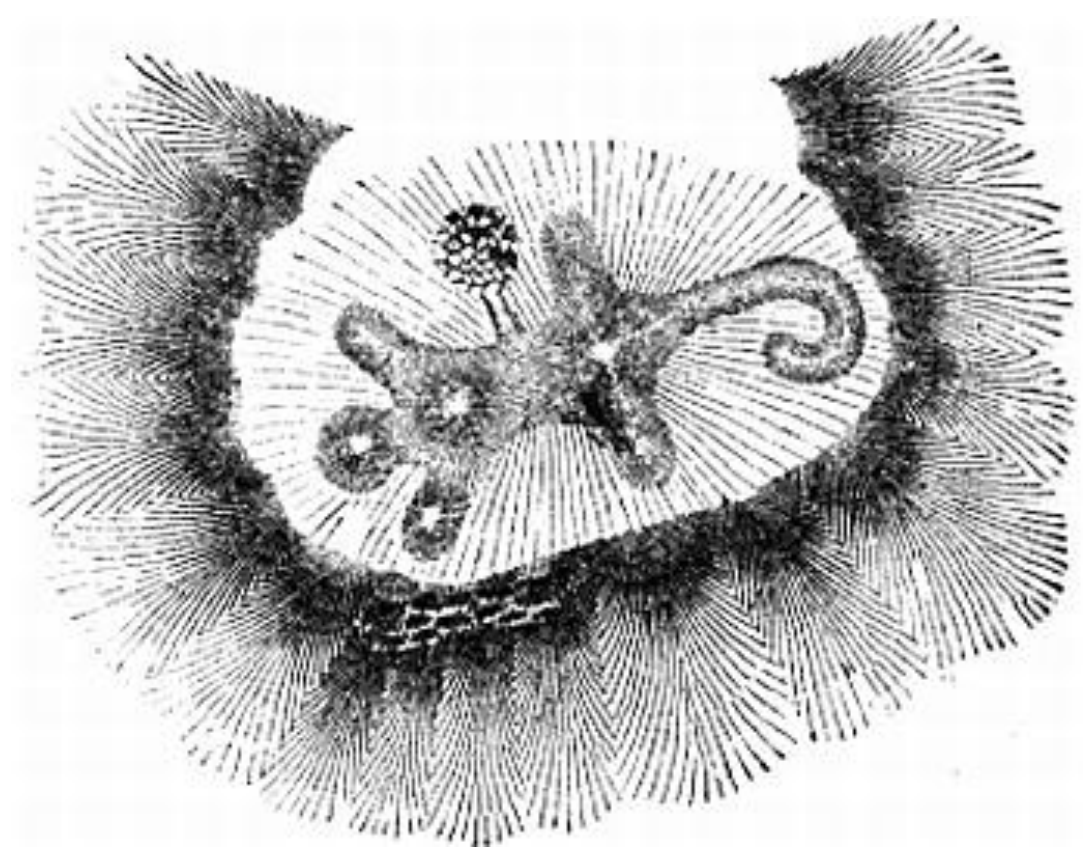

Figure 9: Drawing of Alligator Effigy Mound in Licking County Ohio The American Antiquarian and Oriental Journal, Volume XIII, Page 316

The Native American mounds were a good example of the civilization that existed up until the seventeenth century. Some were burial mounds, some ceremonial, and others part of great cities that once existed. They were planned carefully, with great attention to cosmological placement. By observing these mounds, a greater understanding of the culture, urbanization, and even the astronomical abilities of pre-Columbian societies can be gained. 


\section{Chapter Two}

"Those who raised our ancient tumuli..." 36

European Interactions and Perceptions of the Mounds

The perceptions formed by non-natives of the mounds shaped the future of the mounds, with misunderstandings and Manifest Destiny often playing a key role. The non-native encounters with mounds dated at least back to the sixteenth century when the Spanish came through. Beginning around the end of the eighteenth century, scholarship began to emerge that contemplated the origins of the great mounds and other earthworks located across much of eastern North America.

One of the earliest misconceptions on the origins of the mounds was that they had been built by Welsh explorers. The Welsh theory likely originated from a man named John Dee, who presented a "Title Royal" to Queen Elizabeth I in 1580. The majority of "Title Royal" has been lost, but a summary exists that stated "The Lord Madoc, sonne to Owen Gwynedd, Prince of Northwales, led a Colonie and inhabited in Terra Florida or thereabouts." ${ }^{37}$ John Dee claimed that the son of Owen Gywnedd, an ancient Welsh king, had sailed to America and settled there sometime in the thirteenth century. The son was referred to as both Madoc and Madog. The “Title Royal” was crafted in order to support Sir Humphrey Gilbert's expedition of colonization. Since the Title said that a Welsh colony had at one point existed, Dee most likely intended for it give the British some ability to claim the New World.

Other writings of the sixteenth century took up the idea of Madoc establishing a colony in the New World. David Powel, in 1584, wrote a history of Wales that mentioned Madog's voyage.

\footnotetext{
${ }^{36}$ Monthly Magazine, British Register, Volume 51, (R. Phillips, 1821), 543. In this passage, the American Antiquity Society explicitly divided antiquities into “...three classes. 1. Those belonging to Indians. 2. To people of European origin; and 3. Those of that people who raised our ancient forts and tumuli."

37 Jerry Hunter, "Myth and Historiography: One Hundred and Sixty Years of Madog and the Madogwys." The Yearbook of English Studies 46 (2016): 37-55. doi:10.5699/yearenglstud.46.2016.0037.38
} 
He did not mention an idea that would become prevalent two centuries later, that Madog had intermarried with tribes and created a group of "white Indians'. Rather, David Powel wrote of America as being pristine and that Madog had gone back to the land that "at he had seene without inhabitants; and vpon the contrarie part, for what barren and wild ground his brethren and nephues did murther one another: he prepareda number of ships, and got with him such men and women as were desirous toliue in quietnes." ${ }^{38}$ This idea ran starkly against the reality, which was a land that was full of inhabitants. In 1686, Thomas Herbert wrote Some Years Travels where he narrated Madog/Madoc's voyage. In his version, the land was not uninhabited--native people existed, though they were a threat to the Welsh settlers. Unlike Powel, Herbert's version has a less happy ending for the Welsh; they ended up dying in America. However, he said they left traces including "the language they left there, the religion they taught the Savages." 39 Both narratives gave the British some degree of claim to North America.

38 David Powel, The historie of Cambria, now called Wales, (London: Rafe Newberie and13Henrie Denham, 1584), pp. 227-28.

${ }^{39}$ Thomas Herbert, Some years travel into divers parts of Asia and Afrique : describing especially the two famous empires, the Persian, and great Mogull ... as also, many ... kingdomes in the Orientall India and other parts of Asia ; together with the adjacent iles ... with a revivall of the first discoverer of America. (London, UK: Blome and R. Bishop, 1638), 359-60. 


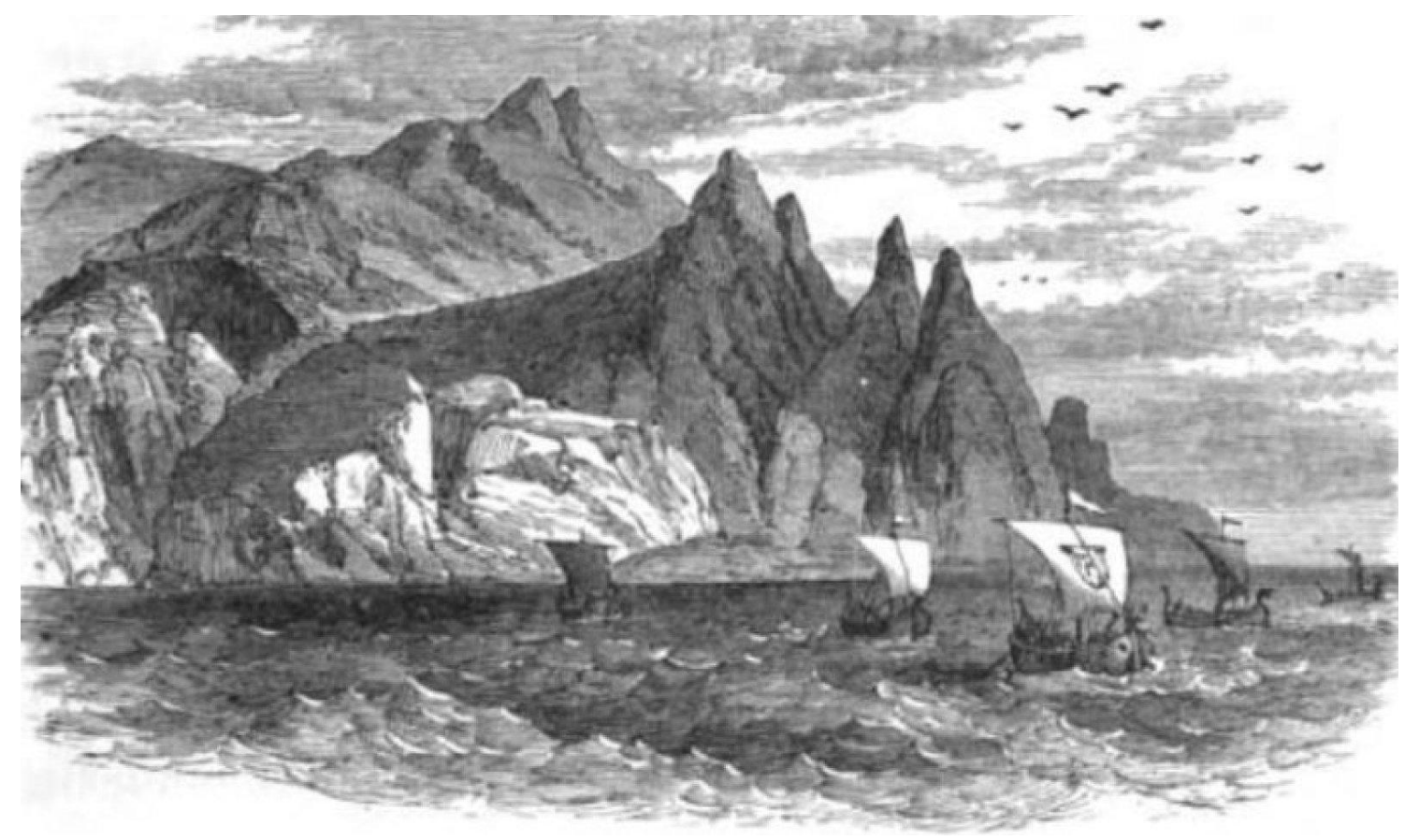

Figure 10: Depiction of Madoc leaving Wales in 1170 going to America A Popular History of the United States, William Cullen Bryant / C. Scribner's Sons (1888)

The story of Madog/Madoc persevered through the centuries, though it became altered. In 1624, John Smith, who had become the historian for Virginia, wrote that Madoc had journeyed to the Americas. ${ }^{40}$ Towards the end of the eighteenth century John Filson (the author of the Daniel Boone novels) wrote in his history of Kentucky that some of the tribes in Kentucky were related to the Welsh. He admitted that some people, those "vain and petulant" might make fun of this idea, but he was confident in his evidence. Along with the language similarities that an acquaintance had told him about, Filson believed the mounds were evidence since they showed that the Americas had to have been inhabited by a "nation farther advanced in the arts of life than the Indian." This idea, that the Indigenous people were not advanced or civilized enough to have

\footnotetext{
${ }^{40}$ John Smith, The Generall Historie of Virginia, New-England, and the Summer Isles. Documenting the American South. University of North Carolina at Chapel Hill. http://docsouth.unc.edu/southlit/smith/smith.html
} 
built such antiquities would persist for a good many years. ${ }^{41}$

In the nineteenth century, a linguist, Henry Kerr, had lived among a tribe he deemed the "Mnacedens." It is unclear what tribe he was referring to. In Kerr's book, Travels through the Western interior of the United States, 1808/16, with some account of a tribe whose customs are similar to those of the ancient Welsh, he laid out the several similarities he supposedly saw. He said that they had had a highly valued book that seemed, to him, to have Welsh origins. ${ }^{42}$ Noah Webster, around 1877, began writing on the similarities between ancient American mounds and Welsh mounds, including the tendency to put a stone at the top. In 1799 there were claims that a burial mound containing bodies wearing Welsh breast plates was found. ${ }^{43}$ This was mentioned in The American Pioneer, a monthly periodical, in a letter from a T.S. Hinde, though today no one is in possession of those breastplates. There may have been some truth to the idea that the Welsh had made contacts with Indigenous Americans, since pre-Columbian contact is not unheard of. That a small group of Welsh came to the Americas is reasonable, but for them to have built the mounds is a stretch of the imagination.

Many European settlers and scholars suggested that the mounds and cities that they found in America were built by the lost tribes of Israel. ${ }^{44}$ The theory was based on a part of the Bible. The scripture held that Jacob, the grandson of Abraham, the Patriarch, was blessed by God and renamed Israel. Jacob had twelve sons, and each one became the father of one of the twelve tribes of Israel. Later, after the death of King Solomon, the state of Israel was divided into two.

\footnotetext{
${ }^{41}$ John Filson, The discovery, settlement and present state of Kentucky, and an introduction to the topography and natural history of that ... country. Also colonel Daniel Boon's narrative of the wars of Kentucky. Oxford: Oxford University. 1793.

${ }^{42}$ John Filson, The discovery, settlement and present state of Kentucky, 77.

${ }^{43}$ John S William, The American Pioneer: A Monthly Periodical, Devoted to the Objects of the Logan Historical Society; Or, to Collecting and Publishing Sketches Relative to the Early Settlement and Successive Improvement of the Country, 1842. 373.

${ }^{44}$ Roger G. Kennedy, Hidden cities: the discovery and loss of ancient North American civilization (New York: Free Press, 1994), 225.
} 
In the south, the tribes of Jacob's sons Judah and Benjamin were loyal to the Davidic house, while the ten northern tribes became ruled by monarchs. The Old Testament maintained that the tribes of Judah and Benjamin were the ancestors of the majority of the Jewish people. The ten other tribes eventually disappeared; they were assumed lost. Centuries later, some individuals began to suggest that they had somehow ended up in North America. ${ }^{45}$

James Adair was an ardent supporter of the lost tribe theory. ${ }^{46}$ He was an Irish deerskin trader and an Indian agent for the South Carolina colony who worked with tribes such as the Choctaw and Chickasaw in the mid to late eighteenth century. His book, The History of the American Indians, published in 1775, started as an effort to clear his name from a claim that he had been involved in a complicated scheme to persuade the Choctaws to ally themselves in trade with the French or Spanish rather than the English colony of South Carolina. His book, however, quickly evolved into a detailed description of the tribes during that time, and it became a very important primary source for understanding the nature of southeastern Indian culture. Although his ethnographic descriptions have been very valuable to students of southeastern Indian culture, his explanations of the origins for the indigenous peoples of North America have not been very helpful. In his book, Adair argued that the indigenous people were descended from the lost tribes of Israel. He pointed to the mounds found throughout the South and Midwest, and wrote that the mound building was similar to Laban and Jacob raising a mound of stones in the Bible.

Adair wrote:

Laban and Jacob raised a heap of stones, as a lasting monument of their friendly covenant....Many of those heaps are to be seen, in all parts of the continent of NorthAmerica; where stones could not be had, they raised large hillocks or mounds of earth, wherein they carefully deposited the bones of their dead, which were placed either in earthen vessels, or in a simple kind of arks, or chests. ${ }^{47}$

\footnotetext{
45 “Where are the Ten Lost Tribes?” NOVA Online. Pbs.org. http://www.pbs.org/wgbh/nova/israel/losttribes.html

${ }^{46}$ Kathryn Braund, "James Adair," Encyclopedia of Alabama.

47 James Adair, History of the Indians, (London: Edward \& Charles Dilly, 1775).
} 
Adair uses the Biblical story of Laban and Jacob as proof of the mound-builders in America being tied to the Biblical tribes. In Adair's opinion, the raising of a mound of stones was a striking similarity to the mounds built out of dirt, in an effort that would have taken years.

Prominent campaigners for the lost tribe theory were the Mormons. Joseph Smith, the founder of the Church of Latter Day Saints, said that he had a vision showing him that the indigenous American people were descendants of Abraham. ${ }^{48}$ Smith and the Mormon leadership called on their followers to convert Indians to their faith and encouraged their people to treat the indigenous people fairly.

Smith also wrote in a letter to his wife that he was convinced that the plains of Illinois were the land of "the Nephites." ${ }^{49}$ The city of Cahokia was in Illinois, and there were numerous other mound structures in the region as well. According to the Book of Mormon, the Nephites were one of the Israelite groups that crossed to the Americas, the others being the Lamanites, the Jaredites, and the Mulekites. In an expedition to the supposed land of the Nephites, Smith discovered the body of a man in a burial mound. Based on a vision, he said that the body was Zelph, a white warrior of the Lamanites who had been killed during battle. Wilford Woodruff, one of the journal keepers during the expedition, wrote the following about the discovery of Zelph in 1834:

We visited one of those Mounds and several of the brethren dug into it and took from it the bones of a man.

We visited one of those Mounds: considered to be 300 feet above the level of the Illinois River. Three persons dug into the mound \& found a body. Elder Milton Holmes took the arrow out of the back bones that killed Zelph \& brought it with some of the bones in to

\footnotetext{
http://olivercowdery.com/texts/1775Adr1.htm

${ }^{48}$ Joseph Smith, The Papers of Joseph Smith, vol. 2: Journal, 1832-1842, ed. Dean C. Jessee (Salt Lake City, UT: Deseret Book Co., 1992), 69-70.

${ }^{49}$ Dean C. Jessee, The Personal Writings of Joseph Smith, rev. edn (Salt Lake City, UT: Deseret Book Co., 2002), 324 .
} 
the camp. ${ }^{50}$

The behavior of the Smith expedition towards 'Zelph' and his remains contradicted their message of friendliness towards the indigenous people and their heritage. Despite encouraging fairness, at the same they took a corpse from its ancestral burial ground and ransacked the mounds, taking skulls and other remains with them. Despite the significance the indigenous people had to the Mormon religion, this did not stop the Mormons from eventually breaking from their rule of civility. When indigenous people would not give up their land and resources in Utah, church leaders approved attacks on indigenous people who resisted. ${ }^{51}$

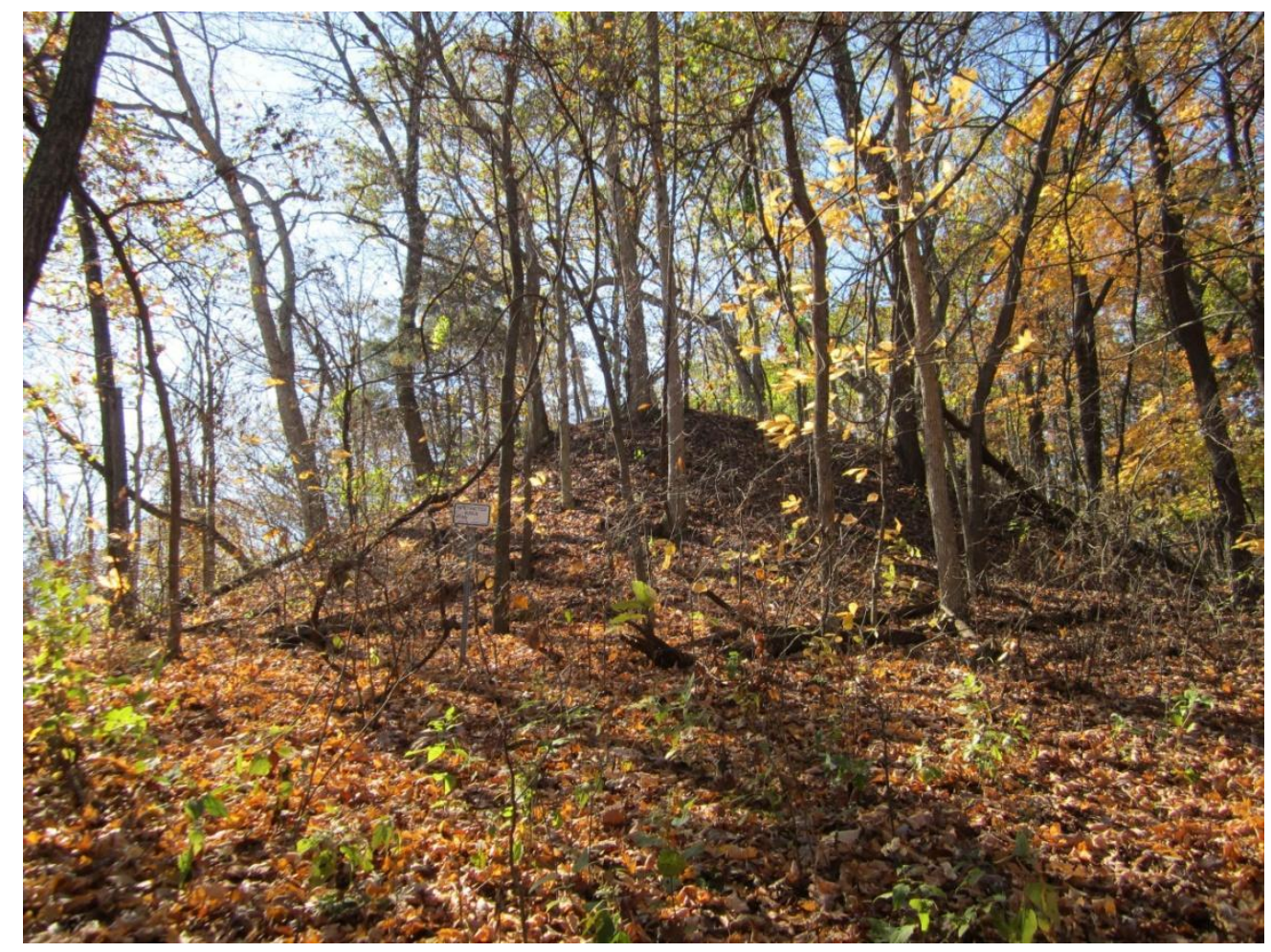

Figure 11: Zelph's Mound, also known as Naples-Russell Mound in Pike's County, IL Wikipedia, Creative Commons

More than a hundred years after Adair's book in 1883, scholars were still promoting the

\footnotetext{
${ }^{50}$ Wilford Woodruff, Wilford Woodruff's Journal, ed. Scott G. Kenney, 9 vols (Midvale, UT: Signature Books, 1988), 1:10.

51 "Mormons and Native Americans: A Historical Overview" http://www.onlinenevada.org/articles/mormons-andnative-americans-historical-overview
} 
"lost tribes" theory. Timothy Jenkins, a biblical scholar, published The Ten Tribes of Israel: Or the True History of the North American Indians. Jenkins pointed to a number of literary sources to support his theory, but the mounds are the most significant part of his argument. Jenkins wrote that he had "the testimony of a number of the most eminent men of America to sustain our position. $"{ }^{, 52}$ Included among the proponents of the theory, he said, were "eminent men" such as the Quaker leader William Penn. The theory did much to lead to misunderstandings of Native American history during that era, for it steered the public away from appreciating that these people had been here for thousands of years and had developed their own civilizations and cultures. Still, the argument provided one benefit: if religious leaders from Penn to Jenkins believed the Native people were descended from Israelite tribes, then that meant Europeans and American Indians possessed a common historical and cultural tradition. That belief encouraged some non-natives to call for better treatment for Indians. ${ }^{53}$

There were individuals who, while still possessing misconception about the mounds origins, argued for their preservation. In 1813, 28-year-old Henry Brackenridge was making a study of the Louisiana Purchase area on behalf of Thomas Jefferson. Brackenridge was a lawyer, superintendent, forester, historian and U.S Congressman. ${ }^{54} \mathrm{He}$ was unique in the fact that he argued passionately for recognizing Cahokia as the heritage site it was and pointed out the disparities between how governments treated the archaeological structures of Rome and the ancient works in the Americas. He described Cahokia in his work Views of Louisiana, published in 1814 , and in the letters he wrote to Thomas Jefferson in 1813 while completing his research. In a letter to Jefferson in July, 1813, he expressed his frustration with the public's dismissal of

\footnotetext{
52 Timothy Jenkins, The Ten Tribes of Israel: Or the True History of the North American Indians (Houck and Smith, 1883).

${ }^{53}$ Kennedy, Hidden cities, 226.

54 "BRACKENRIDGE, Henry Marie, (1786 - 1871)." Biographical Directory of the United States Congress. Congress.gov http://bioguide.congress.gov/scripts/biodisplay.pl?index=B000732
} 
Cahokia's achievements and specifically mentions Monks Mound.

I am perfectly Satisfied that cities Similar to those of Ancient Mexico, of several hundred thousand souls, have existed in this part of the country....There are not less than one hundred mounds, in two different groups; one of the mounds falls little short of the Egyptian pyramid Mycerius. When I examined it in 1811, I was astonished that this stupendious monument of Antiquity Should have been unnoticed by any traveller: I afterwards published an account in the newspapers at St Louis, detailing its dimensions describing its form, position \&a, but this, which I thought might almost be considered a discovery, attracted no notice: ... who will pretend to speak with certainty as to the Antiquity of America - ... They have called it the New world, as though its formation was posterior to the rest of the habitable globe. ${ }^{55}$

Brackenridge's letter to Jefferson was a powerful defense of the achievements of the Cahokian people, but it was a rare one. This is only a portion of his letter and to read it in full gives an even sharper image of his feelings on the site. Unfortunately, Brackenridge had more reasons for concern. Cahokia was left unprotected for another century and a half, and farmers came in and plowed up much of the national treasure. Of the one hundred twenty mounds Brackenridge saw, only eighty remain today.

The lost tribe were not the only group to which the mounds were falsely attributed to. There was a multitude of scholars who believed the mounds were built by Hindus who had traveled from India. John Clifford, Samuel Rafinesque, and Caleb Atwater were some of the prominent promoters of this theory. In the early $19^{\text {th }}$ century Clifford wrote many letters on the mounds origins, connecting them to India, that were published in a small magazine in Kentucky. Clifford died not long after these writings were published and today they can be read in a book entitled John D. Clifford's Indian Antiquities: Related Material by C.S. Rafinesque. The book also gathers the writings and maps of Rafinesque's, who was a friend and collaborator of Clifford. Clifford and Rafinesque used mounds as supporting evidence, saying that the styles

\footnotetext{
${ }^{55}$ Henry M. Brackenridge to Thomas Jefferson, 25 July, 1813. The National Archives. https://founders.archives.gov/documents/Jefferson/03-06-02-0269
} 
were similar in India and the Americas. ${ }^{56}$

Rafinesque wrote a review of a book published by Caleb Atwater, a lawyer and amateur archaeologist, entitled Description of the Antiquities Discovered in the State of Ohio and Other Western States written in 1820. Caleb Atwater was of the same belief as Rafinesque and Clifford: Atwater put the "antiquities" of America into three separate categories; ones that belonged to "modern" Native Americans, ones that belonged to those of European origin, and "those of that people who raised our ancient forests and tumuli." ${ }^{57}$ He believed that these forts built in ancient America might have been to protect against the ancestors of what he deemed the "modern Indian." 58 Some of his other evidence was that murex shells were found "within twenty miles of Lexington Kentucky, in an ancient work in the Kentucky mounds." 59 This was important to Atwater because murex shells were rare in India and were gifted to their god Mahadeva. Of course, murex shells are naturally found all along the North American coast. Rather than suggesting a connection to India, the presence of them seems to suggest that a trading network between the Kentucky mound dwellers and other tribes was active in ancient America.

The other main evidence Atwater put forth was that he considered the people who had built these ancient works to be idolaters, that is they worshipped the Hindu gods. Atwater describes a triune vase found at the mounds near the Caney Fork River in Tennessee which he claimed depicted the heads of the Hindu gods Brahma, Vishnoo, and Siva. ${ }^{60}$ John Clifford also made the same claims and Clifford seemed to be a basis for Atwater's writings. Atwater wrote

56 John D. Clifford and Constantine Samuel Rafinesque, John D. Clifford's Indian Antiquities: Related Material by C.S. Rafinesque. ed Charles Boewe.( Knoxville, TN: University of Tennessee Press, 2000), 14-15.

${ }^{57}$ Caleb Atwater, "Description of the Antiquities Discovered in the State of Ohio and Other Western States." Transactions and Collections of the American Antiquarian Society, Volume 1. American Antiquarian Society, 120.

${ }^{58}$ Caleb Atwater. "Description of the Antiquities Discovered in the State of Ohio and Other Western States." 122.

${ }^{59}$ Ibid, 241.

${ }^{60}$ Ibid, 238-240. 
that the reader will "In this idol, one proof at least, that the people who raised our ancient works, were idolaters, and, that some of them, worshipped gods resembling the three principal deities of India." ${ }^{61}$ Rafinesque agreed with the theory that the mounds were built by descendants of travelers from India, but he also criticized Atwater for being too dismissive of the mounds as temples for religious ceremonies. ${ }^{62}$

Clifford, Rafinesque, and Atwater all had a knack for thorough research, but they also contributed to the othering of Native American. Rather than giving them credit where credit was due, they attempted to attribute the ancient works as being created by another group, one that they claimed may have even been chased away by the "modern Indian."

Sometimes this race that had been chased away was credited to a specific people, such as Hindus--other times it was attributed to a mysterious "vanishing race," one that was supposed to be possibly white. Sometime this white race was given a specific identifier, such as the Welsh, or ancient Vikings-- which Benjamin Barton suggested in his Observation on Some Parts of Natural in $1785 .{ }^{63}$ Barton went further to say that after these Vikings were driven out by the Indian, they went to South America and became the "Toltecs," who he said ended up ruling the land before the Aztecs.

Another example is William Bertram's research. Bertram visited areas throughout the country, doing natural history research. He even visited a Creek tribal town (in the site of present day Palatka, Florida), where the chief greeted him on a pavilion on top of a mound. However Bertram believed, since the mounds he saw were apparently different than some of the other earthen mounds he observed, that "The Creeks or present inhabitants have a tradition that this

\footnotetext{
${ }^{61}$ Ibid, 241.

62 "Rafinesque's Review of Atwater" John D. Clifford's Indian Antiquities. Ed. Charles Boewe. (Knoxville, TN: University of Tennessee Press, 2000.) 99-109.

63 Robert Silverberg. The Mound Builders, (Athens, OH: Ohio University Press, 1986,) 32
} 
was the work of the ancients, many ages prior to their arrival and possessing the country." ${ }^{64}$

Despite evidence of similar practices, he still was sure that the mound builder tradition had originated with people different than the Indians he was encountering.

In 1829, Andrew Jackson used the idea of a race being driven away as an explanation for the Indian Removal Act of 1830 that was soon about to go into effect. He stated, in his Second Annual Message to Congress, that:

Humanity has often wept over the fate of the aborigines of this country, and Philanthropy has been long busily employed in devising means to avert it, but its progress has never for a moment been arrested, and one by one have many powerful tribes disappeared from the earth...In the monuments and fortresses of an unknown people, spread over the extensive regions of the West, we behold the memorials of a once powerful race, which was exterminated or has disappeared to make room for the existing savage tribes. ${ }^{65}$

The "once powerful race" was a reference to this "vanishing race" that the Indians had displaced or exterminated and the memorials were most likely the mounds. Jackson emphasized that it was perfectly acceptable to remove the Indigenous people from their land because the Indian was savage, made up of a few groups of hunter/gathers, and had been responsible for the genocide of the people (theorized to be possibly white) who had built the magnificent mounds. Jackson's removal resulted in the deaths of at least 4,000 Cherokee and many more Eastern Native Americans, even though he spoke against the supposed genocide of the mound builders. ${ }^{66}$ Through those ideas, the removal was justified in Jackson's speech.

Despite the harm this theory did, it continued to be a theme in writings of the nineteenth century. A vanished race was perfect for romanticizing and often lamented over in poetry. In William Gilmore Simms poem, "The Mountain Tramp" there is a section that discusses the

\footnotetext{
${ }^{64}$ Silverberg, The Mound Builders, 37.

${ }^{65}$ President Andrew Jackson's Case for the Removal Act First Annual Message to Congress, 6 December 1830. Library of Congress.

${ }^{66}$ Russell Thornton, "Cherokee Population Losses during the Trail of Tears: A New Perspective and a New Estimate." Ethnohistory 31, no. 4 (1984): 289-300. doi:10.2307/482714.
} 
mound builders. Simms was a southern writer in the mid nineteenth century, who was known for writing sweeping tales of the antebellum South, as well novels, stories, and poems that had to do with Native American life. The poem reflects on the builders of the mounds and the fate they

had.

I guessed the red man's fate, or those

Who first upon those mountains sway'd,

And sank beneath the red man's blows,

Too fiercely savage to be stay'd;

Who left their shrines without a name

Their tombs without a record! Where, The story of their ancient fame,

Their deeds, the Gods they sought in pray'r,

Perchance, in sacrifice! In vain,

The progress o'er each silent frame,

Each sullen mound and ruin'd tower.

Oh! For the spell of magic pow'r

To burst the casements of the dead,

And bid the sage or hero rise

To tell us, why his people fled

Or how they toil'd and fought, and bled,

And what their triumphs, ere the doom,

That shut them in the speechless tomb.

No voice to answer! All is still.

The echoes die along the hill,

And mock me with my words again!

Yet shall the genius of the place

In days of potent song to come

Reveal the story of the race, 
Whose native genius now lies dumb.

Yes, Fancy by Tradition led

Shall trace the streamlet to its bed,

And well each ancient path explore

The perish'd trod in days of yore.

The rock, the vale, the mound, the dell,

Shall each become a Chronicle. ${ }^{67}$

The lines "Who first upon those mountains sway'd, And sank beneath the red man's blows," is the line that most clearly points to the idea that a mysterious, likely, white, race was driven out by the so-called modern Indian. The literature and the scientific views of the vanished race were two sides of the same coin; one circulated in academic circles and the other reached out to the public.

Ancient Monuments of the Mississippi Valley was an official report published in 1848 by the Smithsonian Institute. Ephraim Squier, an archeologists and Edwin Davis, a physician conducted researched of earthworks in the Mississippi Valley. It is a thorough document, complete with illustrations and maps, many of which are used in this paper. Squier and Davis mostly avoided speculation, but at one point they stated that the mound builders were a separate race than the Indian that were "much superior to their successors." 68 They reference Samuel Morton's Crania Americana, which was published in three volumes between 1839 and 1849. He stated that a race's intellect could be judged by the size of the cranial capacity. A large skull equaled superior intellect and a smaller skull indicated lower intellect. These studies of Morton's resulted in his theory of polygenism, the idea that every race was the product of separate

\footnotetext{
${ }^{67}$ William Gilmore Simms, An early and strong sympathy: the Indian writings of William Gilmore Simms. Edited by John Caldwell Guilds and Charles M. Hudson. (Columbia: University of South Carolina Press , 2003).

68 Edwin Davis and Ephraim Squier, Ancient Monuments of the Mississippi Valley. (Washington DC: Smithsonian Institution, 1948. 273.
} 
creation. $^{69}$

The separate race theory was carried on into the latter half of the nineteenth century by the 1854 manuscript Types of Mankind by Josiah Nott and George Glidden, both of whom admired Samuel Morton and his theory of polygenism. Josiah Nott was a physician in the mid nineteenth century and Glidden was an Egyptologist. Nott and Glidden consistently refer to the Indigenous Americans as a barbarous race. They stated that "The semi civilized communities of America seem to at all times to have been hemmed in and pressed upon by the more restless and warlike barbarous tribes. ${ }^{70}$ In their opinion, the mound builders had been closer to civilization than people that were supposedly the ancestors of the present day Native people.

The mound builder theories not only harmed the mounds, but also were dangerous for the wellbeing of Indigenous people. The idea that the Indian was a barbarous race that killed off the mound builders led to justification for the mistreatment of the Indigenous people. In Types of Mankind Nott and Glidden quoted Doctor James Cowles Prichard as saying that "The barbarous races of America (excluding the Toltecs), although nearly as low in intellect as the Negro races, are essentially untamable...Our Indian tribes submit to extermination..." This idea that the Native people that Anglo-Americans interacted with in the nineteenth century were responsible for the destruction of a more admirable race led to disastrous results.

One of more wild theories was the Atlantis hypothesis. Like the mound builders, Atlantis was lost, which made it a perfect origin story for the mound builders. Ignatius Donnelly was a Congressman and amateur scientist in the nineteenth century who wrote Atlantis: The Antediluvian World in 1882 which explored the origins of different races, including the mound builders. His thesis was that the mound builders came from the south and that later "the savage

\footnotetext{
69 Adam Dewbury, "The American School and Scientific Racism in Early American Anthropology", in Darnell, Regna; Gleach, Frederic W., Histories of Anthropology Annual, 3, p. 142

${ }^{70}$ George Glidden and Josiah Nott, Types of Mankind (Cambridge, MA: Harvard University, 1873), 277.
} 
races came who drove them south or exterminated them." Donnelly suggested that they had forced the mound builders to retreat to Mexico. ${ }^{71}$ Interestingly, Donnelly did recognize the urban planning and used the example of the four cardinal direction alignments to support his argument that mound builders had reached considerable civilization. ${ }^{72}$

While many of these theories were the sincere beliefs of the writers, some were outright hoaxes. A man named William Pidgeon wrote a book in 1855 entitled Traditions of Dee-CooDah and Antiquarian Researches, that stated that a native man, De-coo-dah, had told him that he was descended from the Elk People who were likely of Danish descendent. The mounds of the north were built by the Danish Elk People and the southern ones were built by the Mexicans. ${ }^{73}$ The two groups had fought and then the Indian had taken over since the Elk People were weak from fighting. In 1886, T.H. Lewis discredited Pidgeon's claims by pointing out that Pidgeon had not visited most of the sites and dismissed most of his observations as a hoax. ${ }^{74}$

While some, such as Adair, Smith, and Clifford refused to acknowledge that ancient native people could have constructed the earthworks of North America and tried to connect Cahokia and the mound builders to the lost tribes, a few individuals were willing to contemplate the idea that Cahokia was a site built by the native residents of the continent.

Lucien Carr was another nineteenth century scholar who broke the mold in the belief that anyone other than the Indigenous people had built the mounds; rather than saying the lost tribes of Israel or people the descendants of Atlantis had built them, he stated that they were built by people directly related to the tribes today. Carr was the assistant curator of the Peabody Museum in the late nineteenth century and published more than dozen books in the fields of archaeology,

\footnotetext{
${ }^{71}$ Ignatius Donnelly, Atlantis: The Antediluvian World. (New York City, NY: Harper and Brothers, 1882$) 375$.

72 Mann, 76.

${ }^{73}$ James Adovasio and Jake Page, The First Americans: In Pursuit of Archaeology's Greatest Mystery (New York: Modern Library, 2003), 22.

${ }^{74}$ James Adovasio and Jake Page, The First Americans: In Pursuit of Archaeology's Greatest Mystery, 22.
} 
anthropology and ethnology. Carr did not agree with the idea that it had to be a more cultured people that had built them that had been driven out by the current Indigenous inhabitants. $\mathrm{He}$ pointed out that the Indigenous people in his time were sun worshipper, that the mound builders also appeared to be sun worshippers and would make sense that they were related. ${ }^{75}$ In his discussion of other theories, Carr remarked that the mound builders “...are, at best, a mythical people, who owe even their imaginary existence to the necessity of accounting for a state of affairs that is, in great part, assumed; and of course any standard by which to judge the works they are supposed to have executed must vary with the fancy of the writer of the exigencies of the argument." ${ }^{76}$ In his opinion, the majority of theories on the mound builders as a separate race were simply imagination on the part of the writer.

\footnotetext{
${ }^{75}$ Lucien Carr, The Mounds of the Mississippi Valley, Historically Considered. (Oxford, UK: Oxford University, 1883), 38 .

${ }^{76}$ Ibid, 59 .
} 


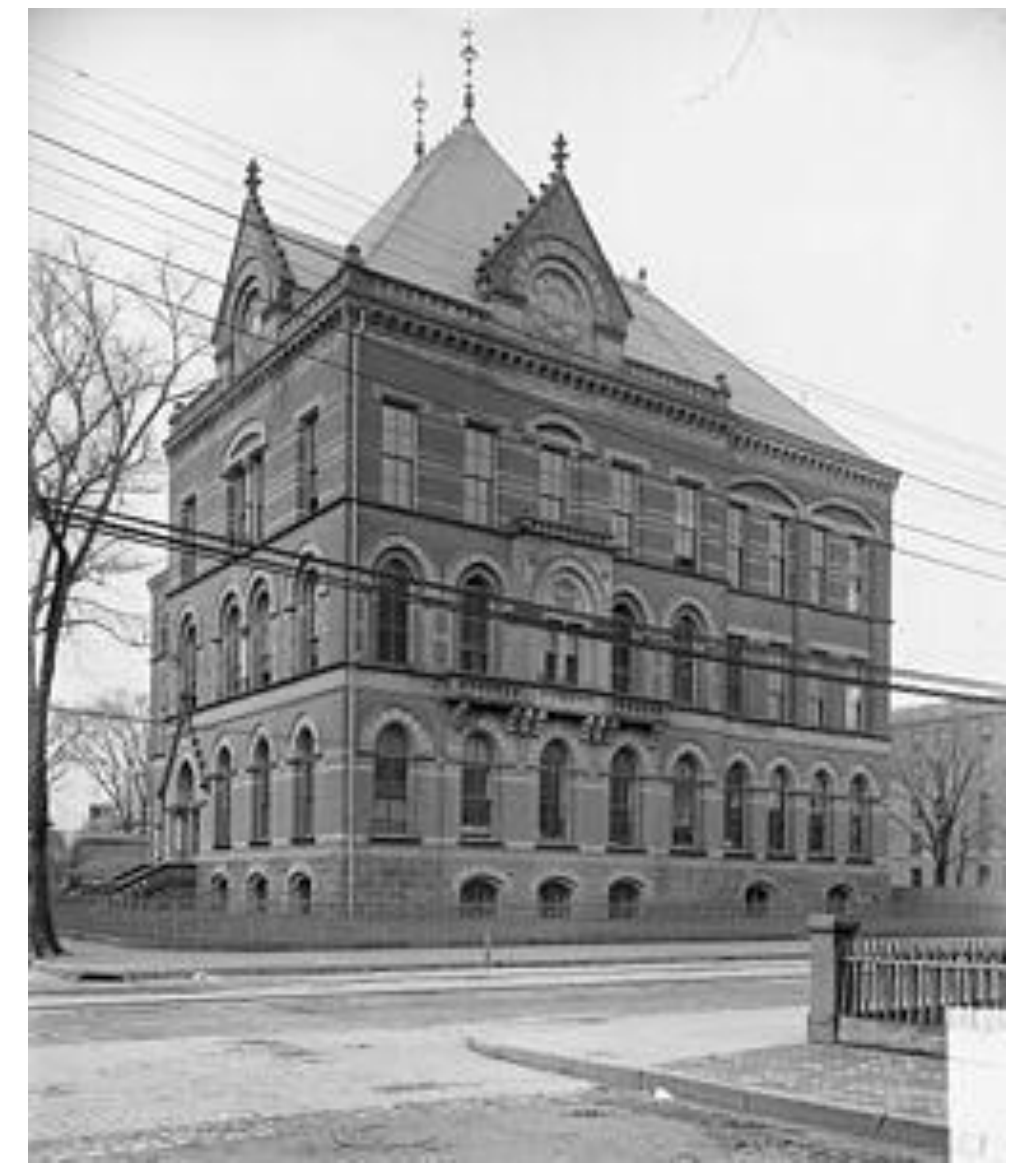

Figure 13: Old Peabody Museum building, completed in 1876 Detroit Publishing Co, Wikimedia Common.

John Wesley Powell, the director of the Bureau of Ethnology since its founding in 1879, had a strong interest in the mounds which led him to fund Cyrus Thomas, an ethnologist and entomologist, to make a thorough report of the mounds. ${ }^{77}$ His view when starting the research was opposite to Powell's - Thomas believed that mounds were indeed the work of a vanished race that was not associated with the "Modern Indian." ${ }^{78}$ However, by the end of his research his opinion had changed. He easily took down different components of the vanished race argument; Thomas stated that "Indians were competent to build such structures. Their supposed engineering

\footnotetext{
${ }^{77}$ Bennie C. Keel, "Cyrus Thomas and the Mound Builders" Southern Indian Studies, Volume XXII. 1970, 8. ${ }^{78}$ Ibid, 9.
} 
problems are nothing but the fancy of some writers." ${ }^{, 79}$ Once this argument was made, published in an official United States Smithsonian Institute report, Work in Mound Exploration of the Bureau of Ethnology, opinions seemed to shift. Just like the Squier and Davis's official report or the romanticized poetry on the mound builders had influenced opinion, this new official statement became influential in people's minds.

Even today, misleading theories on the mounds abound. One only has to do a cursory search on Google to find websites that claim that aliens--in particular the idea of the Nephilim of Genesis--built the mounds. Sites such as science-frontier, unexplainable.com, and alienhub.com pop up, as do a fair number of documentaries that claim aliens were somehow responsible for the mounds. An article by Dr. Greg Little entitled "Did Ancient Astronauts Influence American Mound Builders' Beliefs about Death?” suggested that ancient aliens visited the Americas and through their interactions with mound builders informed their belief system. ${ }^{80}$

In the 1960s, Erich Von Daniken began publishing a series of books that claimed that aliens or "astronauts" had visited various places throughout the world in ancient times. His most well-known book is Chariot of the Gods? which was made into a documentary film. He wrote several other books, all which followed the same idea. Von Daniken argued that the effigy mounds in South America and the lines of Nazca, had to be built by aliens since they could be seen from the sky. In Signs of the Gods? Daniken suggested that Poverty Point (a mound site in Louisiana) was one of the many "laid out according to the master plan of a global building committee." ${ }^{81}$ In other words, he believed a group of aliens had planned the entirety of ancient architecture.

\footnotetext{
${ }^{79}$ Cyrus Thomas, Report on the mound explorations of the Bureau of ethnology (Washington, DC: United States Smithsonian Institute, 1894), 631.

${ }^{80}$ Greg Little, "Did Ancient Astronauts Influence American Mound Builders' Beliefs About Death?” MessagetotheEagle.com

${ }^{81}$ Erich Von Daniken, Signs of the Gods? (Old Saybrook: Tantor eBooks, 2011), Chapter 4.
} 
In 1976, Barry Fell brought the outdated theories concerning the origins of the Native Americans back into the public sphere in his book America $B C{ }^{82}$ The book brought back the Lost Tribes theory, claimed that Vikings ruled New England, that Egyptians used rivers to land in Iowa and that the mounds were a result of these groups. ${ }^{83}$ Fell was a zoology professor who taught at, shockingly, Harvard. His theories were generally dismissed by archaeologists and historians, but the book itself flew off the shelves, with the first copy selling out. ${ }^{84}$

Like the theorists that came before him, Barry Fell's book was a dismissal of Native Americans. These misconceptions can be traced as far as the sixteenth century, when Britain claimed the Welsh had landed in the New World in the twelfth century, hoping this claim would give them a better chance of taking the New World for their own. Examining primary sources on the mounds origins helps build a larger picture of the racial ideas towards Native Americans at the time. Even today, while historians and anthropologists fully acknowledge the mounds as being of Native American origin, the outlandish theories of aliens and other mystical beings being the mound builders, are still present on internet forums and are explored in widely watched YouTube videos.

\footnotetext{
${ }^{82}$ Barry Fell, America B.C.: Ancient Settlers in the New World. (New York: York Times Book Company, 1976).

${ }^{83}$ Peter Frawley, "Barry Fell and His Big Idea: Wherein a Harvard Zoology Professor Tells the Tale Of All the Folks Who Got Here Before Columbus." The Harvard Crimson, 1977.

${ }^{84}$ Ibid.
} 


\section{$\underline{\text { Conclusion }}$}

The mounds suffered greatly because of the misinformation that existed in the nineteenth century. Starting around the 20th century, there started slow journey to preservation. There were three turning points for the mounds in the late nineteenth century and the beginning of twentieth century that paved the road to better preservation.

The first was the creation of the Smithsonian Bureau of Ethnology. John Wesley Powell, the same Powell who had commissioned Cyrus Thomas, was its first director and had previously lobbied for an Ethnology bureau. ${ }^{85}$ Powell believed in the theory of the mounds being the work of the Indigenous tribes, rather than of now vanished lost tribes or immigrants from India.

The second turning point was the enactment of the American Antiquities Act. It was introduced in 1906 by John Fletcher Lacey, a representative from Iowa and was enacted on June 8th $1906 .{ }^{86}$ This act gave authority to the president to give protection to "historic landmarks, historic and prehistoric structures, and other objects of historic or scientific interest that are situated upon the lands owned or controlled by the Government of the United States." ${ }^{87}$ While this still somewhat relied on the president to establish this protection, which would depend on the president's view of conservation, it provided a solid foundation for the protection of the mounds. Unusually, Hopewell Culture National Historical Park was preserved quite early, in $1923 .{ }^{88}$

The National Historic Site Act of 1935 also provided protection to sites that were deemed of historic merit. In 1972, there was the Convention concerning the Protection of the World's Cultural and Natural Heritage which lead to the development of UNESCO World Heritage Sites.

\footnotetext{
${ }^{85}$ Richard B. Woodbury, and Nathalie F. S. Woodbury, "The Rise and Fall of the Bureau of American Ethnology." Journal of the Southwest 41, no. 3 (1999): 284.

${ }^{86}$ Archaeological Method and Theory: An Encyclopedia, edited by Linda Ellis, pp.33-35, Garland Publishing Co., New York and London, 2000. Francis P. McManamon

87 American Antiquities Act of 1906, 16 USC 431-433. https://www.nps.gov/archeology/tools/laws/antact.htm

88 “Basic Info." Hopewell Culture National Historical Park https://www.nps.gov/hocu/planyourvisit/basicinfo.htm
} 
Along with being a National Historic Landmark Cahokia is UNESCO World Heritage site.

These acts and services have done much to protect ancient sites. However, even within services aiming for protection, there are still points of debate. The American Antiquities Act also required that any artifacts discovered at these sites be placed in public museums--this has resulted in a mixed bag of opinions. While it does much to preserve artifacts from mounds and to protect them from theft, it also had the effect of keeping artifacts from Native communities. The question of whether archaeologists or native communities have more right to the artifacts and human remains has been an active debate, one that resulted in NAGPRA.

NAGPRA or the Native American Graves Protection and Repatriation Act of 1990 was another turning point. This enabled more ability to enact protection of native burial sites and native human remains and opened up ways for tribes to take ownership of what was rightfully theirs. Through NAGPRA, there is support for a process for returning Indigenous cultural items back to descendants and tribes. Mary McDonald pointed out in her essay that "the lesson to take from NAGPRA is that Native Americans should have voice in the discussion of the earthworks". ${ }^{89}$ Through NAGPRA, human remains discovered at the mounds have been reclaimed.

However, NAGPRA is not an immediate fix. There are still ways that it is either disobeyed or gotten around in a "legal" way. An example is a recent occurrence at the Great Circle Mound in Newark, Ohio. A professor and a group of archeology students were planning to dig a trench into the Great Circle's wall, without permission from Ohio tribes. This resulted in Barbara Crandell, an elder from the Cherokee tribe discovering the dig by accident, while coming down to the Great Circle Mound for her regular prayer. Upon discovery, she and other Natives took up vigil at the mound, and when the dig group went to bury their garbage in the

\footnotetext{
${ }^{89}$ Whose Earthworks?: Newark and Indigenous Peoples," In The Newark Earthworks: Enduring Monuments, Contested Meanings, edited by Jones Lindsay and Shiels Richard D., 230-42. University of Virginia Press, 2016. http://www.jstor.org/stable/j.ctt19z38wx.17.
} 
trench dug into the mound, Crandell jumped into the trench in front of the bulldozer. ${ }^{90}$ Crandell was arrested at the Octagon Mound eleven years later for trespassing even though all she was doing was praying at her own heritage site. ${ }^{91}$ While NAGPRA is not always successful and there is still work to be done ensure it is followed, it does give more power to tribal people and is vital for protection of Indigenous sites, remains, and artifacts. The road to preservation for the mounds has been slow and there is still work to be done-it is however, a changed landscape today than it was in the nineteenth century.

The enactment of these organizations and laws has done much to increase the protection of the mounds. Today the mounds are in a much better place than in the nineteenth century. The perceptions of the mounds by non-natives played a role in the lack of protection. While there were many scholars fascinated with the mounds, the contradictory theories about the mounds were to their disadvantage. There was an almost desperate attempt to prove that they were built by people who were not related to the Indians the Europeans were encountering in the nineteenth century. Many of the efforts to force the Native American from their land were "justified" through the argument that they were uncivilized. However, antiquities such as the mounds were often signs of civilization to Europeans. Because of this, the idea that the Indian had built the mounds was often dismissed and theories such as Welsh colonists, Israel Lost Tribes, or an extinct separate race were the preferred opinions. The problem was that these were contradictory opinions, with not many facts to back them up.

The mound builders of pre-Columbian North America constructed a city that was larger in London at the time. The city of Cahokia showcased the cosmos in its urban planning; the

\footnotetext{
${ }^{90}$ Mann, Native Americans, Archaeologists and the Mounds. Volume 14 of American Indian Studies, V. 14. ( Bern, Switzerland: Peter Lang Pub Incorporated, 2003) 302.

${ }^{91}$ Barbara Mann, “The Sacred Places of Unrecognized Peoples.” Indian County Media Network. https://indiancountrymedianetwork.com/history/sacred-places/the-sacred-places-of-unrecognized-peoples/
} 
mounds were aligned to celestial patterns, the city had its own great timekeeping device in the form of Woodhenge, and Monk's Mound is the largest prehistoric structure in North America. Despite this, many non-natives did not notice Cahokia's achievements until the early $20^{\text {th }}$ century. The former vibrant city was used for farming and the building of the mounds was attributed to non-natives in the form of the lost tribes of Israel. The way Cahokia and other mounds were was perceived played a role in the destruction of. Not achieving protection until 1964, Cahokia suffered from the destruction of mounds and theft of human remains and artifacts. This was a result of eighteenth and nineteenth century perceptions and these perceptions delayed in the protection of Cahokia, which was near catastrophic.

These ancient civilizations were replete with urban planning that connected the residents with the cosmos and celestial world, though this was mostly overlooked until the late nineteenth and twentieth centuries. Some of these sites are now preserved as state or national parks, safe from the threat of farming and road construction. Non-native people in the eighteenth and nineteenth centuries, however gave scant acknowledgment to the achievements of the ancient cities. As a result, farmers plowed under important native mounds and earthworks, thieves and artifact dealers stole precious historical objects, and governments allowed ancient structures to fall into decay. In the middle to late nineteenth century, the idea of Manifest Destiny was at its height among many Americans, and this played a role in how non-native individuals and governments treated places such as Cahokia

The mounds were a unique problem for Anglo-Americans in the nineteenth century-they were faced with hard evidence that Indigenous people fit into European ideals of a civilized society, but for the sake of the New World that could not be accepted. Multiple theories tied to the origins of Native Americans appeared when it came to discussing the mounds--not limited to 
the Lost Tribes, the Welsh, and a mysterious separate race. By looking at one piece of architecture, through studies of the mounds--known now as clearly of Indigenous origin--and the misconceptions and neglect of them gives a better understanding of the racial ideas of the time. 


\section{Bibliography}

\section{Primary Sources:}

Adair, James. History of the Indians. London: Edward \& Charles Dilly, 1775. http://olivercowdery.com/texts/1775Adr1.htm

Atwater, Caleb. "Description of the Antiquities Discovered in the State of Ohio and Other Western States." Transactions and Collections of the American Antiquarian Society, Volume 1. American Antiquarian Society, 1820.

Brackenridge, Henry M., to Thomas Jefferson, 25 July, 1813. The National Archives. https://founders.archives.gov/documents/Jefferson/03-06-02-0269

Clifford, John and Constantine Samuel Rafinesque. John D. Clifford's Indian Antiquities: Related Material by C.S. Rafinesque. ed Charles Boewe.( Knoxville, TN: University of Tennessee Press, 2000).

Daniken, Erich Von. Signs of the Gods? (Old Saybrook CT: Tantor eBooks, 2011).

Davis, Edwin and Ephraim Squier. Ancient Monuments of the Mississippi Valley. (Washington DC: Smithsonian Institution, 1948. 273.

Fell, Barry. America B.C.: Ancient Settlers in the New World. New York: York Times Book Company, 1976.

Filson, John. The discovery, settlement and present state of Kentucky, and an introduction to the topography and natural history of that ... country. Also colonel Daniel Boon's narrative of the wars of Kentucky. Oxford University. 1793.

Frawley, Peter. "Barry Fell and His Big Idea: Wherein a Harvard Zoology Professor Tells the Tale Of All the Folks Who Got Here Before Columbus." The Harvard Crimson, 1977.

Glidden, George and Josiah Nott, Types of Mankind. Cambridge, MA: Harvard University, 1873.

Herbert, Thomas. Some years travel into divers parts of Asia and Afrique : describing especially the two famous empires, the Persian, and great Mogull ... as also, many ... kingdomes in the Orientall India and other parts of Asia; together with the adjacent iles ... with a revivall of the first discoverer of America. London, UK: Blome and R. Bishop, 1638.

Jackson, Andrew. President Andrew Jackson's Case for the Removal Act First Annual Message to Congress, 6 December 1830. Library of Congress.

Jenkins, Timothy. The Ten Tribes of Israel: Or the True History of the North American Indians. Springfield, OH: Houck \& Smith, 1883.

Jessee, Dean C. The Personal Writings of Joseph Smith, rev. edn. Salt Lake City, UT: Deseret Book Co., 2002.

Keel, Bennie C. "Cyrus Thomas and the Mound Builders." Southern Indian Studies, Volume XXII. 1970,

Little, Greg. "“'Did Ancient Astronauts Influence American Mound Builders' Beliefs About Death?" MessagetotheEagle.com

Monthly Magazine, British Register, Volume 51, R. Phillips, 1821, 543.

de Oviedo, Gonzalo Fernández y Valdés, The General and Natural History of the Indies in by $\mathrm{t}$ Rushforth, Brett and Paul Mapp. Colonial North America and the Atlantic World: A History in Documents.(Abingdon: UK, Routledge, 2016)

"Rafinesque's Review of Atwater" John D. Clifford's Indian Antiquities. Ed. Charles Boewe. University of Tennessee Press, 2000.

Smith, Joseph. The Papers of Joseph Smith, vol. 2: Journal, 1832-1842, ed. Dean C. Jessee. 
Salt Lake City, UT: Deseret Book Co., 1992.

Smith, John. The Generall Historie of Virginia, New-England, and the Summer Isles. Documenting the American South. University of North Carolina at Chapel Hill.

Thomas, Cyrus. Report on the mound explorations of the Bureau of ethnology. Washington, DC: United States Smithsonian Institute, 1894.

William, John S.. The American Pioneer: A Monthly Periodical, Devoted to the Objects of the Logan Historical Society; Or, to Collecting and Publishing Sketches Relative to the Early Settlement and Successive Improvement of the Country, 1842. 373.

Woodruff, Wilford. Wilford Woodruff's Journal, ed. Scott G. Kenney, 9 vols. Midvale, UT: Signature Books, 1983.

\section{Secondary Sources:}

Advasio, "Cahokia Layout.” Illinois State Museum. http://www.museum.state.il.us/RiverWeb/landings/Ambot/prehistory/mississippian/techn ology/fac-cahokia-layout.html

Berkhofer, Robert F. The white man's Indian: images of the American Indian, from Columbus to the present, Ann Arbor, MI: The University of Michigan, 1979.

Braund, Kathryn. "James Adair." Encyclopedia of Alabama.

Cahokia Mounds: Ancient Metropolis. Ancient America. VCR.

Ellis, Linda. Archaeological Method and Theory: An Encyclopedia. Garland Publishing Co., New York and London, 2000.

Garraghan, G. J. "The Trappist of Monks Mound. " Illinois Catholic Historical Review Vol. 8 No. 2 (Oct. 1925), pp106-136 http://penelope.uchicago.edu/Thayer/E/Gazetteer/Places/America/United_States/Illinois/_ Texts/journals/IllCHR/8/2/The_Trappists_of_Monks_Mound*.html

Hively, Ray and Robert Horn. "Geometry and astronomy in prehistoric Ohio." Journal for the History of Astronomy 13, no. 4 (1982).

Iseminger, William. Cahokia Mounds: America's First City. Mount Pleasant SC: Acardia Publishing, 2010. Pg 121-135.

Kennedy, Roger G. Hidden cities: the discovery and loss of ancient North American civilization. New York: Free Press, 1994.

Magli, Giulio. Mysteries and Discoveries of Archaeoastronomy: From Giza to Easter Island. Springer Science \& Business Media, 2009.

Mann, Barbara. "The Sacred Places of Unrecognized Peoples." Indian County Media Network. "Mormons and Native Americans: A Historical Overview." Online Nevada.

Pauketat, Timothy R. (2004). Ancient Cahokia and the Mississippians. Cambridge University Press. pp. 88-93.Mound 72." University of Wisconsin Milwaukee. http://www4.uwm.edu/archlab/cahokia/mound72.cfm

Sliverberg, Robert. The Mound Builders. (Athens, OH: Ohio University Press, 1986)

"Where are the Ten Lost Tribes?" NOVA Online. Pbs.org. http://www.pbs.org/wgbh/nova/israel/losttribes.html

Woodbury, Richard B. and Nathalie F. S. Woodbury. "The Rise and Fall of the Bureau of American Ethnology." Journal of the Southwest 41, no. 3 (1999). 